Aboriginal and Torres Strait Islander Art 



\section{Aboriginal and Torres Strait Islander Art}

\section{An Anthropology of Identity Production in Far North Queensland}

Gretchen M. Stolte 
First published 2021

by Routledge

2 Park Square, Milton Park, Abingdon, Oxon, OX14 4RN

and by Routledge

52 Vanderbilt Avenue, New York, NY 10017

Routledge is an imprint of the Taylor \& Francis Group, an informa business

(C) 2021 Gretchen M. Stolte

The right of Gretchen M. Stolte to be identified as author of this work has been asserted by her in accordance with sections 77 and 78 of the Copyright, Designs and Patents Act 1988.

All rights reserved. No part of this book may be reprinted or reproduced or utilised in any form or by any electronic, mechanical, or other means, now known or hereafter invented, including photocopying and recording, or in any information storage or retrieval system, without permission in writing from the publishers.

Trademark notice: Product or corporate names may be trademarks or registered trademarks, and are used only for identification and explanation without intent to infringe.

British Library Cataloguing-in-Publication Data

A catalogue record for this book is available from the British Library

Library of Congress Cataloging-in-Publication Data

A catalog record has been requested for this book

ISBN: 978-1-350-09723-0 (hbk)

ISBN: 978-1-003-08436-5 (ebk)

Typeset in Minion Pro

by Newgen Publishing UK

Cover image: Visual Mosaic, 2010, digital image,

Cultural Group; Yidinji (@ lan Jensen)

Back cover image: Weres Segur, 2010, acrylic on canvas,

Cultural Group; Erub Islander (C Robert Thomas Pau) 
Aboriginal and Torres Strait Islander peoples from Queensland are advised that this book contains names of deceased people that they may wish to avoid seeing. All readers are advised that images and artworks are used with the artists' permission and that artists retain the cultural and artistic copyright to those images. 



\section{Contents}

List of Figures viii

List of Tables $\quad x$

Preface xi

Acknowledgements $\quad$ xv

1 Art and identity 1

2 Curios and artefacts $\quad 19$

3 The history of the studio $\quad 57$

4 The studio today 81

5 Disciplining the artist 103

6 Value creation and the market $\quad 125$

7 Design elements 145

8 Cultural content 167

9 True North 187

$\begin{array}{ll}\text { Bibliography } & 215\end{array}$

$\begin{array}{ll}\text { Index } & 227\end{array}$ 


\section{Figures}

1 Photo included in the Queensland government's Public Relations Bureau's News Bulletin from 28 November 1958. Source: Queensland State Archives Item ID502314, Correspondence, Aboriginal and Torres Strait Islander.

2 Early design schematic for the Queensland Native Creations sticker of authenticity which was to be placed on each item for sale, 1959. Source: Queensland State Archives Item ID502314, Correspondence, Aboriginal and Torres Strait Islander.

3 QAC artworks sent to Aboriginal Arts Management Association for evaluation in the manner of the Central Desert dot painting style, 1991. Source: Queensland State Archives Item ID646421, Correspondence, Aboriginal and Torres Strait Islander.

4 Jack O'Chin, shadowbox from Cherbourg (1962). From the collection of Peg Jackson. Courtesy Michael Aird. Photo credit: The author.

5 Inside the studio, 2010. Photo credit: The author.

6 Ian Jensen, Identity (2010), digital work. Photo credit: The artist.

7 Allan Martin, Cultural Identity: Totems (2010), vinyl-cut print on paper. Photo credit: The author.

8 Pellista Lammon, Coral Garden (2010), acrylic on canvas. Photo credit: The author.

9 Lynelle Flinders, Seed Time (2010), acrylic on canvas. Photo credit: The author.

10 Peter Morrison, monochromatic jug exercise using a biased colour palette, detail (2010). Photo credit: The author.

11 Example of the Bauhaus experiment in process (2010). Photo credit: The author.

12 Various boomerangs purchased during the 2010 fieldwork period. Photo credit: The author.

13 Lynelle Flinders, untitled landscapes (2010), gouache on paper. Photo credit: The author. 
14 Peter Morrison, On the Farm (right) (2010), water colour on paper. Photo credit: The author.

15 Peter Morrison, Feasting (2010), linoprint. 2010. Photo credit: The author.

16 Liz Saveka, Everyday People (2010), mixed media on paper. Photo credit: The author.

17 Liz Saveka, untitled (2010), screenprint and batik. Photo credit: The author.

18 Charlie Sailor, Rebes (2010). Pen and ink. Photo credit: The author.

19 Design elements commonly found within the studio. Graphic: The author.

20 Charlie Sailor, Gabba Gabba (2010), acrylic on canvas.

Photo credit: The author.

21 Allan Martin, Lizard (2010), vinyl-cut print on paper.

Photo credit: The author.

22 Darren Blackman, Moon Cycle (2010), batik. Photo credit: The author.

23 Peter Morrison, Diving Down (2010), vinyl-cut print on paper. Photo credit: The author.

24 Charlie Sailor, Torres Strait Pigeon (Dewmer) (2010), acrylic on canvas. Photo credit: The author.

25 Ian Jensen, 'Bigunu' (Shield) > Clan Design (2010), acrylic on canvas. Photo credit: The artist.

26 Ian Jensen, Creation Series \#1 (2010), digital work. Photo credit: The artist.

27 Tommy Pau, Kab Kar (2010), digital work. Photo credit: The artist.

28 Tommy Pau, Zogo Le Ra Pone (2010), digital work. Photo credit: The artist.

29 Tommy Pau, Mask Dancers (2010), vinyl-cut print on paper. Photo credit: The author.

30 Leon Namai, Kaurareg Nation (2010), vinyl-cut print on paper. Photo credit: The author.

31 Leon Namai, Seven Brothers (2010), vinyl-cut print on paper. Photo credit: The author.

32 Eddie Sam, Weris (2010), acrylic on canvas. Photo credit: The author. 


\section{Tables}

4.1 Active participants in the research 85

$\begin{array}{lll}7.1 & \text { List of design elements used in the studio } & 151\end{array}$

7.2 Frequency of design elements in the studio 152

7.3 Frequency of design elements in the studio according to how artists identify 153

$\begin{array}{ll}7.4 & \text { Distribution of fauna types within the studio } \\ & 160\end{array}$

$\begin{array}{lll}7.5 & \text { Distribution of bird species within the studio } & 162\end{array}$ 


\section{Preface}

In 2010, I entered 'the field' that liminal space anthropologists create in order to answer the questions that plague them. I came to study First Nations identity in Australia and I ended up studying First Nations identity in myself. My entry into the field, as an anthropologist and art historian, was immediately challenged by the people I wanted to work with - not because of who I was as I thought I was (as a 'whitefella') but because of who I was as students perceived me to be (as a 'blackfella'). This acceptance as a First Nations person was to impact everything. I wanted to conduct research at the TAFE (a technical school) campus inside an art studio exclusively for Aboriginal and Torres Strait Islander artists in Cairns, Queensland. Research into First Nations peoples needs to start with consultation of those most impacted by the research. As such, I sought to talk with people who could provide some direction for my research project. I was called into the offices of the lead instructor for the Aboriginal and Torres Strait Islander arts course. We had emailed and spoken on the phone, but this was the first time I was to actually meet Elaine Lampton - the woman who would facilitate and guide my research in ways I would never have thought possible. Elaine greeted me warmly. It took only a few moments for her to grasp what I wanted to do and less time still for her to redirect me.

'Identity', she said. 'It's always about identity. Who are we? What are we about?' She brought out a piece of paper and began to draw as she spoke. An artist to the core, Elaine can never talk without drawing at the same time. Even in restaurants when we met for dinner, she would pull out a napkin and start scribbling on it to make her point. 'See this line?' She dragged her pencil roughly and quickly across the paper. 'This is an Aboriginal line, marked by an Aboriginal woman. Who I am makes this line what it is.'

Her confidence falters, however, when she shows me examples of her finished artwork. One is a painting of a car screaming down a road in a highly abstracted background. The entire piece is without a strong sense of place - the car could be anywhere; the space around it any space. The image transcends time and place and emotes a feeling of reckless motion and movement. Elaine tells me about the experience she had when visiting the central desert of the Northern Territory 
where a car had almost run her down. She looks at the painting though and sighs. 'It's not really that Aboriginal of an art piece, is it?'

The way Elaine vacillated between believing in the Aboriginality of a single line while dismissing her painting as not 'Aboriginal' enough would be my first glimpse into this tension of being a First Nations artist in contemporary times. On one hand, she knew who she was and where she came from and was proud of her Aboriginality. However, she understood her art in completely different terms. I was pondering this dichotomy when she stood up with a sudden energy and asked me, 'Do you want to meet the artists?'

I hesitated as this was the last thing I was prepared for, but I followed her into the studio and stood awkwardly in front of twenty unsmiling students. Elaine introduced me as a university student who was doing research about First Nations art and then, in that unexpected way which I was never to get used to, she turned to me and asked me to speak. 'Tell them about your project', she told me. Doctoral students are always asked to explain their research - more often than not because they cannot. The answer fluctuates throughout the research and writing process, but to have to speak about my project in front of a sea of hostile faces was confronting. I had come to Cairns to find a research project which mattered to Aboriginal and Islander artists and I was certainly not prepared - not even remotely prepared - to articulate the project in any clear fashion. I blurted out the first thing I thought of and told them the story about my grandmother.

My grandmother, Capella Francis Smith, was born on a Native American Nez Perce (Nimi'ipuu) Reservation in eastern Washington in the United States. Her mother was Josephine Foley, a Nez Perce woman, and her father was Clinton LeBreiox, a French-Canadian man (there are romantic family rumours that he was an astronomer). I told them about how my grandmother had been removed from the Reservation when she was 2 years old and adopted by a white family. I told the class that in my country, I was not considered Native American because of this complex history and the way First Nations tribes defined their enrolment criteria. I said that in Australia, identifying as First Nations was different. Aboriginal and Torres Strait Islanders could identify and connect with their heritage in ways which were unique and special. I said that I wanted to understand that process and that since I was an artist I wanted to understand that process through art. I told the story as a way of communicating what I understood to be the unusual position of First Nations Australians and my own experiences seemed the most straightforward way to demonstrate my intentions without a lot of academic jargon. 
Elaine thanked me and told the students that if anyone wanted to talk with me about what I had said, I would be available in the theory room - a small, private room adjacent to the studio. She encouraged the students to talk with me and I went to wait. I did not honestly think anyone would come and talk with me. I was not even ready to talk with people and I was about to leave the studio and head back to my hotel when I noticed a woman coming to speak with me. This was my first meeting with Rita.

Rita sat next to me and did not even allow me to speak before she started talking. 'You know what you were saying in there? You are brainwashed. Your government has brainwashed you into believing you're not Native. You know what? You're Native. You just don't know it yet, but you're Native, alright.' I sat there gaping at her, not really able to take in all she was saying. 'Did you notice those boys who were ignoring you? Their heads turned to you when you talked about your grandmother. They recognised you as Native. You can't ignore it anymore.'

We talked for maybe ten or fifteen more minutes before Rita went back into the studio. I promptly left the TAFE - without saying good bye or even thanking Elaine for her help. I was quite honestly taken aback by the assertions that I might call myself a Native American; that I could actually claim my ancestry was something I had never considered an option. It honestly floored me to the point where I had to escape the studio.

This declaration of my own Indigeneity by Rita echoed throughout my time in the field as word quickly spread about my heritage. I was introduced as 'the Native American' in social situations. I was asked questions about my 'culture' such as 'how do you say hello in your language?' I was even assumed to have cultural knowledge about traditional stories, artwork and food. It was an incredible insight into the type of assumptions Aboriginal and Torres Strait Islander peoples face. In some ways, this was the ultimate participant observation exercise.

This assertion of my identity - enforced through positive environments and total acceptance - affected me personally in many ways. People considered me First Nations and opportunities opened as people treated me differently because of this identity. I realized it was a very real 'power' to hold, and I felt an enormous responsibility. If I was going to be treated as a First Nations person, I needed to $b e$ a First Nations person, right? I ended up doing what I saw other Aboriginal and Islander people do when they found themselves in a similar position of unknowing: I bought and read books about Nez Perce history, traditional art styles and current events; I connected with an online group of $\mathrm{Nez}$ 
Perce language speakers who accepted my declarations of kinship and I began the process of learning Nimiputímt, the Nez Perce language; I began to learn more about my grandmother's people and I can now extend my lineage back five generations. The biggest visual representation of this exploration of identity was learning traditional beadwork techniques and processes. I have always declared my Nez Perce heritage as a child to anyone who would listen and I have been a beadworker since I was a teen, but these experiences in Cairns were something new. The process of connecting and declaring was at times a very emotional journey but ultimately a very rewarding one as well.

All of this illustrates a very important point in the politics of First Nations Australian art production. Elaine, who was dark-skinned and has never doubted or have had cause to doubt her Aboriginality, faltered when presenting an art piece which she felt was 'not very Aboriginal. Less than an hour later, I was declared, with my light skin and complete lack of cultural knowledge, as First Nations and within six months was producing beaded works which were taken as 'authentic' pieces. Why would Elaine's painting be considered less Aboriginal? Why was my beadwork taken as 'authentic'? Put simply, there are factors which determine the acceptance of artworks based on popular expectations of what a First Nations work should look like and what it cannot look like. This book reflects on these issues of traditionalism, authenticity and Indigeneity and explores how expectations of Aboriginal and Islander works influence, affect and shape the production of those artworks. I focus on not only the voices of First Nations artists in Cairns but also the deep history these voices grew up in. Part ethnography, part history, this book hopes to bridge the gap between a confidently drawn line and a melancholy dismissal. 


\section{Acknowledgements}

I would like to acknowledge the Yidinji people, the Traditional Owners of land on whom this research was conducted. I pay my respects to your Ancestors, the Yidinji people of today and your emerging leaders and elders of tomorrow. The cover of this book, Visual Mosaic, by Yidinji artist Ian Jensen represents 'jili' or the eye and reflects never losing sight of one's traditional and cultural values of the past while also focusing on one's dreams and aspirations for the future. Visual Mosaic was chosen to acknowledge my time on Yidinji country, your welcoming of me as a visitor and your support of this research. In particular, I acknowledge the Yidinji Elder Seith Fourmile and your contributions to your people and the wider Cairns community. In my language, qe'ciyéw'yew (thank you).

For the research on Queensland Aboriginal Creations (QAC), there were many people who helped me and showed a keen interest in exploring this history. I want to thank Richard Bell, Bruce McLean, Dr Paul Memmott, Theresa Chelepy-Roberts, the staff at the Queensland State Museum, the staff at the Department of Community Services in conjunction with the Queensland State Archives, especially Kathy Frankland, and the Queensland State Library. John Conroy and Michael Aird were particularly wonderful in helping me see beyond the published accounts and archival records in order to understand the lived experience of QAC. Marshall Bell was generous with his own research and support of this project and his writings on Aboriginal art are indispensable. $\mathrm{He}$ passed before its completion, and he will be sorely missed. These people gave generously of their time and knowledge, and I am extremely grateful. I could not have stayed in Brisbane for as long as I did if not for the support of Professor Emeritus Bruce Rigsby, his wonderful wife Barbara Rigsby and their granny flat. Thank you both for your welcoming of me into your home. Qe'ciyéw'yew!

There are a number of people who helped develop the Cairns material. Rita Pryce continues to be the most amazing friend, encouraging me to explore my Nez Perce heritage. She started me on a lifelong journey of discovery for which I am eternally grateful. Established artists in the Cairns region were also generous with their time, and thanks go to Zane Saunders, Arone Meeks and Alick Tipoti. Billy Missi sat down with me to discuss some of the finer points of 
his approaches to Torres Strait Islander art and the world is a lesser place without him. Finally, I want to thank Elaine Lampton. Without her help and guidance in the very beginning of this project, I would most certainly have not been able to do what I did.

The student artists who worked on this project with me were simply incredible. Their interest, commitment and the sharing of the details of their lives continue to inspire me. Very special mention and thanks go to three artists who have guided me through this research by their invaluable participation and friendship. Tommy Pau was a huge supporter and advocate of the research from the very beginning and taught me much about Torres Strait Islander art. Tommy was the first student to make me feel welcome in the studio and he broke much of the research 'ice' I had to initially overcome. He included me in his life and his family and special thanks goes to his wife Mamasung for her friendship and support as well. Ian Jensen gave me a huge insight into local politics and the lived realities of the Traditional Owners of Cairns. His support and generosity in sharing his detailed research and personal documentation regarding Yidinji culture was insightful and much appreciated. I want to thank Lynelle Flinders for her friendship and support and ability to bring everything back down to the most crucial and basic aspects of importance.

Nothing could have been accomplished if not for the support and encouragement of my partner, Stephen Oram. He drove through crocodileinfested rivers when I did not want to; talked with Traditional Owners and artists when it was not appropriate for me to do so; and followed me from Brisbane to the Torres Strait Islands and all over Queensland. 'iin'ee héetewise!

All errors remain my own, but all insights remain with the voices of the First Nations peoples who spoke them. 


\section{Art and identity}

'That's deadly!'

It was a phrase I heard often inside the Aboriginal and Torres Strait Islander arts studio at the Tropical North Queensland TAFE in Cairns. It meant wellexecuted or well done and was the highest compliment a person could give an artwork. For Aboriginal and Torres Strait Islanders in Cairns, deadly could also mean so many other things. Anything could be deadly, such as a concept, a project, a success or a moment. Things could be deadly, like movies, clothing or flash cars. Someone asking for a favour would reply with 'too deadly, mate' when it was granted. Ideas could be deadly. When I told artists about my research topic, some responded, 'ah, deadly'. In this instance, the phrase reflected approval and in cases of artworks or dance performances, it was also a mark of admiration.

The opposite of deadly in the studio was 'gammon'. When an artist called a painting gammon, they meant it was of poor quality. People can be gammon if they lie or act falsely. (For example, politicians were frequently referred to as gammon.) When I was subjected to friendly teasing, I was reassured of my good standing with the throwaway remark, 'just gammon'. In this sense, it was similar to saying 'just joking. Gammon had a fluid use within the studio, but it stands in solid opposition to those things and actions that are considered deadly.

The production of deadly (and gammon) works inside the TAFE Aboriginal and Torres Strait Islander arts studio is at the heart of the production of Australian First Nations identity. What makes one painting deadly and another one gammon? What does it mean to be an Aboriginal and Torres Strait Islander art student at a Western institution such as a TAFE? The history of Aboriginal and Torres Strait Islander art production in Queensland, along with the purposeful development of an art market and the effects of government policies in conceptualizing that market, is scattered across countless sources or buried deep in State archives. For the first time, these materials are consolidated in a single volume in order to tell the story of First Nations art production in 
Queensland. This story takes place inside a school where such productions are codified and structured by State goals and requirements even while, at the same time, those spaces are considered 'Indigenous'.

At the heart of art production is how Aboriginal and Torres Strait Islander student artists internalize local, national and historical constructions of First Nations art, Indigeneity and culture. The chapters that follow engage with these issues in order to understand the processes artists go through when entering into the arts market in Queensland. Questions about the relationship between art and First Nations identity production are answered. The anthropologist Howard Morphy proposes that the 'how' question is 'one of the most important questions in the anthropology of art' (2009: 7). How do Aboriginal and Torres Strait Islander artists in Queensland come to use the images they do? In what ways do these images reflect back on their concepts of self? What are the restrictions in such representations and how are such restrictions conceptualized? What are the outside determinants impacting and/or limiting the creative process? What is culture in the sense that Aboriginal and Torres Strait Islander artists use it?

'Culture' was one of the most used words inside the studio. Aboriginal and Torres Strait Islander student artists use the word 'culture' as a form of personal identity. Culture as used in the studio includes language, artefacts, design elements and stories to which they could lay hereditary ownership. Through the emphasis of material objects and language as markers of identity and belonging, one could 'lose' culture in the same way as one might lose car keys or a pair of gloves. This sense that culture could be lost is an internalization of some of the national dialogue about First Nations peoples in Australia. In public perceptions and newspaper articles, First Nations culture has been one of two things: culture as part of the 'Aboriginal' problem (see Sutton 2009) and as those things which are visible and marketable such as artworks and performances (e.g. 'high culture'). This is a perception that will be dealt with in more detail in the following chapters.

As famously prescribed by the anthropologist Bronisław Malinowski, anthropologists collect three forms of social data in the field; these forms surround concepts of 'what people say about what they do, what they actually do, and what they think' (Kuper 1973: 30). The differences between these three concepts are what make up the hallmark of anthropologists' ethnographies, and how these concepts are expressed constitute a form of culture. From an evolutionist and biological perspective of culture (Spencer [1896] 1973), to the distinction between culture and society (Evans-Pritchard 1951: 40), to culture as a mental construct (Erickson and Murphy 2003: 76), to culture 
as 'webs of significance' (Geertz 1973: 5), culture is a vastly complicated and malleable concept for anthropologists. The reality is that the word 'culture' is used uncritically by the general populace and with fierce attention to detail by anthropologists.

The main critique of the culture concept as surmised by the anthropologist Nic Peterson is that there is an implication that 'people with a common culture have a uniformity of beliefs, values and practices that is not found anywhere in the real world, and that such a group of people can be neatly circumscribed geographically, which is rarely the case' (Peterson 2010: 252). In particular is Peterson's observation on how culture is used within Indigenous Australia:

More generally speaking, public discussion and in particular Aboriginal discussion around culture tends to be a discourse of enchantment that often elevates culture to an almost sacred status. Culture is further removed from critical appraisal because it is made so central to personal identity that any criticism of it can seem like an attack on an individual's personal identity. (Peterson 2010: 253)

Inside the arts studio, culture is used as one and the same as identity. How and why this is the case can be understood through the historical misuse of and slippery slope that is the culture concept. Culture not only has been argued as the keystone of the development of anthropology's identity as a discipline (Bennett 2015: 552; Marcus and Fischer 1986) but has also been shown to help create and legitimize racial divisions. The anthropologist Tony Bennett writes that anthropology is 'the discipline which, in one way or another, made nonwhite people into different human beings from white people' (Bennett 2015: 559 referencing W. S. Willis 1999). Graeme Turner writes that in Europe, 'national identity is synonymous with cultural purity' and that 'against such a model, a nation such as Australia looks bogus' (1994: 122). Furthermore, 'settler/ postcolonial societies face enormous problems in articulating a common identity across competing forms of ethnicity and against a history of occupation and dispossession of the original inhabitants' (Turner 1994: 123). Turner argues that identity must be plural - identities not identity (ibid.). As such, one could argue that there must be space for multiple cultures.

This study explores how the arts studio allows for and also limits the possibility of multiple cultural expressions. Despite the call for multiple views and spaces of identities and cultures, Australia's 'multicultural programmes have become increasingly assimilationist ... while perpetuating long-standing forms of racial sequestration with regard to Indigenous Australians' (Bennett 2015: 561). For 
these reasons and many others, Bennett writes that there is good reason why the culture concept has fallen out of favour with anthropologists (2015: 548), but there are some concepts of culture which can be used to understand events inside the studio.

Urban First Nations people are at pains to show their uniqueness from mainstream society due to the longer and more devastating histories of colonization and dispossession. Very remote Australia is constructed as the model upon which such First Nations identity expressions in the studio are built (see Gibson 2013: 5). There are multiple Aboriginalities across Australia, but their essences have been polarized in the binaries of authentic/inauthentic, traditional/non-traditional and remote/urban. Cairns, in particular, has a demographic and sociocultural make-up which is situated awkwardly between the urban and the very remote rhetoric of First Nations lived realities. Most of these discussions about art and identity production take place in a socially constructed dichotomy between remote regions and settled regions. Cairns is both a settled and remote space. First Nations artists describe themselves in both 'authentic' and 'inauthentic' terms. Their artworks are viewed and put forward as both traditional and contemporary, with various degrees and shades of nuance between those two concepts.

Cairns is located in Far North Queensland at the base of the Cape York Peninsula. It is the regional hub for the Cape and all the major government services are available in Cairns, including the region's largest hospital. The City is surrounded by sugar cane fields, bush land, world heritage listed rainforests and the Great Barrier Reef National Park. In 2010, when this research took place, the largest employment sector was the retail trade and accommodation and food services, employing over 25,000 people (Cairns Regional Council 2010a [online]). This was well above the average from the rest of Regional Queensland and made up almost 30 per cent of Cairns' total employment numbers. Cairns continues to be a tourist hub for many different types of activities, and since the global financial crisis of 2007, there has been some hard times for this sector. ${ }^{1}$

During the 2010 fieldwork period, the Cairns-Atherton region encompasses 221,984 people, of whom 23,466 (10.6\%) identify as First Nations and 14,593 (6.6\%) people do not indicate any status (Australian Bureau of Statistics 2012 [online]). In some ways, these high percentages reflect the large number of people moving away from remote areas and into the City as well as those who have lived in Cairns for many generations. These numbers also reflect the Aboriginal communities in areas such as Mossman, Wujal and Yarrabah. In the City of Cairns, this statistical story does not change much as 13,057 (9.3\%) of the 
140,236 total population identify as First Nations (Australian Bureau of Statistics 2012 [online]). Aboriginal and Torres Strait Islanders are not spread across the City evenly, however, as there are pockets where the population is as high as 14 per cent (Gordonvale) and 20 per cent (Manunda) of the total (Australian Bureau of Statistics 2012 [online]).

Physical divisions between First Nations and mainstream populations still exist in Cairns through less draconian principles than Roslyn Kidd (see Kidd 1997) described. Socially, First Nations peoples are noticeably visible across the city. For example, Cairns Central (the major shopping mall in the heart of downtown Cairns) is a huge mix of tourists and locals. Stocklands Shopping Centre, located just 5 minutes up the highway, has a higher visible First Nations presence despite the fact that, on the whole, the shopping centres are very similar with regard to selections. Stocklands is located on the south end of what was locally known as the three 'Ms' neighbourhoods - Mooroobool, Manunda and Manora. I was warned by non-Indigenous locals to stay away from the three Ms neighbourhoods as they were 'known places for trouble' because they were the ones with a high First Nations population. Why people felt the need to even bring this information up in the first place is telling of the forms of racial bias that exist in the region. The TAFE campus is located near the downtown centre of the city but in the centre of family residences and neighbourhoods in Manunda, the highest population of First Nations people in Cairns and a classic M neighbourhood. I stayed on the edge of Manunda - not because of any intimidation of being closer but rather because it was central to the TAFE, the art centres, galleries and the markets. As someone without a car, I needed a central spot easily accessible by bus, cycle or feet. Unsurprisingly, the Three Ms had very poor bus service, making any choice of living there difficult for anyone without a car.

Despite the physical separations of First Nations peoples across Cairns, representations of their art and cultures can be found all over the city. Cairns has a number of galleries, museums and art centres for its rather small population, and this plethora of spaces focusing on art can be seen as a product of the tourist industry. During July of 2011, domestic tourists numbered 324,074 and international tourists were at 70,443 (Dalton 2011 [online]). Almost 400,000 people a month during the tourist season can pass through Cairns and visit its shops, cruise to the Great Barrier Reef and visit the rainforests. The need to both entertain and engage with tourists and their dollars creates many venues to showcase the region.

Increasingly during the 1980s, Aboriginal art was portrayed inside galleries and major exhibitions across Australia more and more, contributing to how 
people see or expect to see Aboriginal art. In 1984, the National Gallery of Victoria staged Kunwinjku Bim, Western Arnhem Land Paintings, followed up by The Face of the Centre: Papunya Tula Paintings in 1985 (Caruana 2000: 458). The 1989 exhibition, Dreamings: the Art of Aboriginal Australia, was on display at the Asia Society Galleries in New York and 'introduced the overseas art public to the richness and diversity of styles, tradition, techniques and narratives encompassed by the phrase "Aboriginal art"' (Caruana 2000: 459). This exhibition introduced Aboriginal culture and religion as well as the political and economic contexts in art production through the analysis of the mediums, styles and meanings exhibited in the artworks on display. The exhibition was a great success, but like many subsequent volumes on Aboriginal art, it included a large gap in that it did not include any Torres Strait Islander art. Admittedly, being completely inclusive was not the purpose of the exhibition or its catalogue nor was it practically possible to include 'everything', but as the second, nationally recognized Indigenous group in Australia, the exclusion of Islander traditions is not insignificant. Dreamings was an incredibly important exhibition in the history of Aboriginal art in Australia, but it must be remembered that it had a narrow focus on a few regions.

The success of the exhibition programme during the 1980s solidified in the public's eye that the type of paintings included in the exhibition represented the scope of traditional Aboriginal art and this is not the case at all. Lorraine Gibson addresses this stereotype head-on in her book We Don't Do Dots: Aboriginal Art and Culture in Wilcannia, New South Wales, asking, 'Why are notions and images of Aboriginal art and culture still dominated by those from the Central and North of the Australian continent, despite most Aborigines residing in the South-East?' (2013: v). As will be demonstrated by the artists inside the TAFE studio, the idea of knowing the 'scope' of Aboriginal art - especially given the exclusion of Torres Strait Islander art production - was to create problems for artists living in Cairns.

The creation of a stereotype and its working on Aboriginal artists from urban and regional areas is not a new idea and is well documented. As already mentioned, Gibson wrote a thorough treatise on the workings of the dichotomy of remote and very remote artists and urban and regional ones in her work (2013). She points out that 'black and white [peoples] both recognise the value of Aboriginal art, but where primary ideas of what makes art, or artists, leaves most Aboriginal people at something of a disadvantage' (2013: 140, original emphasis). Gibson argues that Aboriginal people are drawn into practicing art 'without necessarily endorsing or understanding the field or the players, and, 
therefore, its possible implications' (2013: 140). These implications can be public confrontations in galleries where potential buyers are looking for something specific and the art being represented does not fit those expectations. Lynelle Flinders of the Dharrba Warra Clan north of Cooktown wrote about her own experiences as a curator of Aboriginal and Torres Strait Islander artists in Cairns and the pressure of 'having dots'. She writes:

In 2011, I was part of a group of artists that exhibited in a pop-up exhibition as part of the Indigenous Art Fair in Cairns. This particular morning I was looking after the exhibition when a tourist came rushing through the gallery looking at the art on display. When I asked if I could help in any way he demanded 'where are the dots?' Not really sure what he was on about, I asked 'what do you mean?' He insisted, 'The dot paintings. Where are the dot paintings?' I said 'Sir, that style is associated with central Australia. These paintings are by artists from Cape York as well as from the Torres Strait Islands. We have a different way of expressing our art here.' He said, 'No. I'm looking for dots' and then he walked out. WELL ... I thought. Is this how all Indigenous art is seen? As dots? (Stolte et al. 2015: 67)

In this exchange, dots are not an empty signifier but a direct reference for the art style of the Central Desert region of Australia where 'dot paintings' have become world famous. ${ }^{2}$ Any possible discussions of dot styles in Cape York, such as those of the Wik People of Aurukun, are not even possible in these situations due to the semantic meaning of the phrase 'dot paintings'. 'Dot paintings' do not just mean paintings with dots; they mean paintings from a specific area of Australia. As both Gibson and Flinders have demonstrated, these stereotypes are very real for First Nations artists.

First Nations art is not limited to the fine art galleries in Cairns, and there are many examples of art catering to tourists. Tourist art are those works which are done for the tourist trade and include painted artefacts such as didgeridoos, bullroarers, boomerangs and clapsticks and paintings and prints which depict a certain expression of Aboriginal cultural representation. These works are part of the public conversation on the nature of Aboriginal and Torres Strait Islander art.

A student at the TAFE worked part-time at a shop called Universal Joint selling paintings and didgeridoos. He told me about the buying practices of the owner - saying he respected what went on in the shop on the whole as the owner treated the local artists with respect and paid a fair market price for their labour. Although the paintings were bought on trips to the Northern Territory, 
the didgeridoos were locally made by Yarrabah artisans and were sold for a retail price anywhere between \$200AUD and \$500AUD. Didgeridoos are considered a hallmark of Aboriginal material culture but they are not local to Cairns First Nations peoples. In point of fact, didgeridoos are not local to any Queensland First Nations peoples and yet are made throughout the state for the tourist trade. The student I spoke with did not have issues with selling didgeridoos but did have some trouble with the representation of dot paintings and $\mathrm{x}$-ray works in Cairns, saying that he personally did not want to paint in that way and that the plethora of images from out of state available in Cairns skewed both local artist and tourist perceptions of what local Aboriginal art should be. There is a distinct difference though that must be made in the kinds of shops available and their business practices: those who sell works from local artists and those who sell works imported from Indonesia.

Indonesian-made didgeridoos and boomerangs - as well as paintings, clapsticks and statues - can be found all over the city in speciality shops along the streets and inside shopping malls. Items are decorated with 'Aboriginal' motifs such as cross-hatched lines in red, white, yellow and black. There are 'x-ray' kangaroos, lizards and turtles and didgeridoos covered with 'dot paintings' and concentric circles. Items like these help perpetuate a stereotype of Aboriginal art (Torres Strait Islander styles are not included in this cultural copying) which has a number of unintended consequences on the artists working in the TAFE studio. There are also a number of consequences on the First Nations art market in Cairns as these didgeridoos typically sell for under \$50AUD.

On a trip to Cairns in 2012, I was able to sit down and chat with a proprietor of a small Aboriginal art gallery which sold locally produced paintings and artefacts. Edina Grünewald has been working with local First Nations artists for years through her Didgeridoo Hut shop, located in downtown Cairns near the bus mall. She buys what she calls 'authentic Aboriginal art' and advertises it through signs on her shop door as well as sandwich boards on the street. She protests the unchecked importation of Indonesian artefacts which pass as 'Aboriginal'. Like Universal Joint, the Didgeridoo Hut sells didgeridoos from between \$200AUD and \$500AUD which Grünewald says reflects the fair price she pays the artists. She explained to me some of the unfair business practices which went along with the Indonesian artefacts such as removing the 'Made in Bali' sticker and yet continuing to claim GST importation costs from overall profits. This keeps the prices of the items down. 'Why would you pay $\$ 300$ for a didgeridoo when next door there is one being marketed as "Aboriginal" for only $\$ 40$ ? This totally confuses the buyer!' 
In 2018, the plethora of fake art from Indonesia finally made national headlines. Bob Katter, the Australian federal member for Kennedy, Queensland, published a press release on the issue of fake art. He writes: 'Our First Australians are being taken for a big ride ... it would appear that about $80-90 \%$ of all supposed Aboriginal, Torres Strait Islander artefacts are not made in Australia nor painted or designed in Australia but in fact are made overseas.' The Australian Competition and Consumer Commission alleges that 'the passing off, for commercial gain, of artwork or cultural objects as being hand-painted or made by Australian Aboriginals may be considered within Indigenous Australian communities to be culturally demeaning and their supply and sale has the potential to lead to the undervaluing of authentic Australian Aboriginal artwork. This sentiment is echoed by Jonathon Saunders, a resource and development officer for the Association of Northern, Kimberley and Arnhem Aboriginal Artists (ANKAAA) who writes, 'we're losing an actual authentic expression of Indigenous culture. ${ }^{5}$

The consequences of this preoccupation with very remote sections of Australia and their art styles are manifold. Funding bodies have absorbed this form of being First Nations in their grant schemes and acquittal processes, skewing discussions and concerns towards those of very remote artists. This endeavour to help remote artists leads to policies that are applied to First Nations artists all across Australia. For example, one of the key recommendations for the First Nations arts industry is the creation of an Indigenous Arts Code. The discourse of the Dreamtime - as the exhibition Dreamings has helped define through the emphasis of First Nations art's mythic narrative and of the ceremonial (Sutton 1989) - has permeated popular culture and expectations of First Nations art with unintended consequences. This permeation is illustrated in the Senate Inquiry's recommendations. The recommendations for art practitioners are to take up the Indigenous Art Code and their certificate of authenticity in the sale of artworks. This certificate was meant to prevent carpet bagging and illicit arts practices, a problem which was made quite clear in the Report's findings (see Chapter 8, pp. 97-106). This certificate asks artists for information as outlined by the Report:

a picture of the artist and the work;

a description of the size and appearance of the work;

a description of the story that the art work represents;

the name, location and contact details of the arts centre or association that is identifying the work; and 
an authorising signature from a person representing the art centre or association.

(Senate Standing Committee on Environment 2007: 120)

The example on the very last page of the Report also includes information on the artist's 'skin name' and because the artist is from the Central Desert region, their jukurrpa or Dreaming (Senate Standing Committee on Environment 2007: 235). Certificates of authenticity used in Cairns by the regional art centre hub include some of these pieces of information such as a photo of the artist, a photo of the artwork with dimensions and construction, provenance, a space for the story and the artist's tribal group. Many artists I worked with had a problem with affiliating with a tribal group. Some students do not know their tribal identity they simply identify as Aboriginal or Torres Strait Islander. Most however had issues with answering this question because they possessed a mixed and oftentimes diverse heritage and did not want to limit themselves artistically by using a single label. Tommy Pau, an active participant and figure in this book, commented on his identity this way:

I am an Australian with heritage from Australian Aborigines, Torres Strait Islander, Asia, New Guinea and South Pacific.

Every phase of my life I have been influenced, leaned onto, learnt and experienced one of my blood lines. For example, my Asian influence is through martial arts and Asian food. I connected with my New Guinea bloodline when I lived on my parent's home island with my big ama (my mum eldest sister). I appreciated my Aboriginal bloodline living on the mainland in Aboriginal communities. With a diverse background confusion is always present and one can be lost in developing an identity.

I, therefore, define myself as an Australian and have pride in being called an Australian or Indigenous Australian of Torres Strait decent.

The culture I practice is mainly Torres Strait Islander culture, as it is the culture I was raised up on. But does that makes me solely a Torres Strait Islander because I was raised in that culture? I do not have fuzzy hair or dark skin and I do not speak traditional language. Therefore it is best for me to tell you my identity than it is to be classified by geographical upbringing. I cannot be solely identified by geographical upbringing as it is a gross injustice to my ancestral bloodline that is present in my existence.

Having a label placed on you restricts you from drawing inspiration from a rich background and aids in the denial of a rich ancestral heritage forcing one to create false identities and fit a mould that will have gaps in it. Locale should not 
be a square enclosing artistic inspiration and disabling artist development and creativity for an artist to draw inspiration from his or hers ancestry tree. ${ }^{6}$

Tommy was disappointed at having to put down as his 'tribal group' 'Thursday Island/Erub (Darnley) Island' because he felt it would limit how the art market was going to perceive his work and what he would be allowed to do. This is an example of just one of the many ways in which the First Nations arts industry in Cairns - with all its good intentions - is at odds with contemporary reflections of self and the aspirations of artists. This tension can be framed in part by concepts of culture and how they act upon First Nations peoples.

By far, the most accessible market available to new artists is the tourist trade. With potentially almost 400,000 visitors a month during the Dry Season, tourists are seen as prime buyers for artworks. I met many artists who were once students at the TAFE's First Nations art programme who sold their works at the weekend markets. More of this issue will be discussed in subsequent chapters but suffice to say, with the fine art galleries and commercial galleries offering only intermittent opportunities at best, the tourist trade was the most immediately lucrative avenue for revenue students had at their disposal. Works sold this way however had a different sense of artistic credibility and there were many debates surrounding what was and what was not for the markets.

Some of these issues are mitigated through innovative new markets and one shining example of this is the First Nations run organization, UMI Arts. UMI (as it is commonly referred to) is named after the creole word used often in the Cape region to mean 'you and me'. Established in 2005, UMI Arts is a non-profit organization with an all First Nations board of directors. During its first years, the director was Lisa Michl, a graduate of the TAFE First Nations arts programme. UMI describes itself as 'the peak Indigenous arts and cultural organisation for Far North Queensland, an area that extends north of Cairns to include the Torres Strait Islands, south to Cardwell, west to Camooweal and includes the Gulf and Mt Isa regions' (UMI Arts 2009 [online]). Membership is free for First Nations artists from these regions only. Membership for nonIndigenous arts organizations, or those interested people, is for a fee. UMI's focus is 'to strengthen Aboriginal and Torres Strait Islander cultural practices, including visual arts and crafts, dance, ceremony, storytelling [sic] and music' (ibid. [online]).

UMI puts on an impressive array of activities, events, workshops and exhibitions centred on Aboriginal and Torres Strait Islander arts. Their Exhibition Ready programme takes inexperienced artists through the process 
of designing, preparing and setting up exhibitions. Groups and people who have participated in this event come from all over Cape York. From New Mapoon, to the Torres Strait Islands, to Hope Vale and Yarrabah to local artists and students from the TAFE, the UMI Exhibition Ready programme has catered to a diverse range of artists. UMI also has a monthly art market for artisans, musicians and dancers during the dry season. Once a year, they put on the Big Talk One Fire event which showcases First Nations talent in what they bill as the Far North Queensland's Premier Cultural Festival (UMI Arts 2012 [online]). Recently, UMI has developed their Side by Side Programme where UMI Arts members run workshops for other members to share knowledge and expertise.

As a First Nations peak body, UMI was and continues to be open to criticism about its intentions and objectives. I have been told by some members that UMI has a level of nepotism involved in its practices and the people it chooses for such programmes like Exhibition Ready or Side by Side. Other artists feel that the responsibility and obligations of being involved in higher decision-making processes are not appealing to most artists. The preference is to defer positions of power to others while continuing to make critiques from the outside. It is very difficult for UMI to be all things to all people and I would not debate these views. From personal experience, I have seen artists assert themselves and their identity in dealing with UMI while at the same time I have seen UMI come into its own as an organization that believes in what it is doing and has the confidence to stand against naysayers. The most important aspect about UMI is the fact that it is a First Nations organization which allows for and even stimulates debates such as these with resolutions which are rooted in First Nations agency. There is no other place in Cairns like UMI for First Nations artists and the communities they represent and the organization plays a very important role in developing the rhetoric of the First Nations arts industry in the region. ${ }^{7}$

In order to understand the perspectives on Aboriginal and Islander identity in Queensland through the production of visual material, understanding how did First Nations art begin in Queensland is crucial. Students stepping into the studio are stepping into a specific art historical milieu which influences the way the course is structured, how students see First Nations art and how First Nations art is received publically. How do First Nations students, new to the arts industry, reflect on their sudden newfound identity as Aboriginal or Islander artists? In what ways are the images displayed around town internalized and reproduced in their own artworks? This book explores the kinds of images First Nations artists use in their artworks and why those artists make the choices they do. Further, it looks at the images produced inside the studio - not just the ones 
for exhibit - to try and see if there is a difference between what students put out in public and what they produce privately.

Although many cultural disruptions occurred with the coming of the First Fleet in 1788, artefact production was a continuous process for many communities in remote Cape York regions. Lindy Allen wrote a brief history of collecting in Queensland in the Queensland Art Gallery's Story Place: Indigenous Art of Cape York and the Rainforest catalogue. In it, she writes how contact with 'outsiders' goes back to the 1600s and no doubt included the trade of desirable items (Allen 2003: 30). Early systematic collection of artefacts - what Allen calls 'scientific collecting' - happened during the 1800s and was facilitated by sailing ships travelling around the Cape York region. With the establishments of settlements like Cardwell in 1862 and the Port of Somerset in 1863, easier access attracted 'both collectors and those interested in biological and social evolutionary theories' (Allen 2003: 32). Allen writes that 'museums and collectors alike sourced artefacts from local police, police magistrates and local residents' (2003: 33).

Details on what types of artefacts were collected are indicated through the requests by Queensland Museum director Dr R. Hamlyn Harris; he asked for materials from the Mitchell River Mission such as 'shields, wooden and bark containers, bags and other materials' in 1911 (Allen 2003: 33). Walter Roth, the protector of Aborigines at the turn of the twentieth century, encouraged collecting from regional offices and made Cooktown the 'depot for arranging, sorting and labelling' those artefacts (Allen 2003: 34). Roth especially has been noted for his thoroughness in collecting artefacts and material objects of interest (see Kahn 2008). Allen notes that some two thousand artefacts made their way to the Australian Museum in 1898 (ibid.). Additionally, anthropologists such as Norman Tindale (see Jones 2008), Ursula McConnel (see Perusco 2008) and Donald Thompson (see Allen 2008) all made multiple trips to Cape York, collecting artefacts and taking photographs (Allen 2003: 34). Alfred Cort Haddon's Cambridge expedition to the Torres Strait in 1898 produced a huge collection of artefacts which were published in later years (1935). Of additional interest is Roth's observation that trade was happening between communities and not just between First Nations communities and European settlers. Roth wrote that in 1898, the trade of artefacts had slacked compared to earlier days but noted that bark blankets made by the people of Cardwell were still traded for dilly bags made by the people of Tully River (Allen 2003: 33).

Collecting by anthropologists and museums was one aspect of the engagement between First Nations craftsmen and mainstream organizations. However, with 
such careful collecting and recording of artefacts from an early period, there is a misunderstanding and a tension in the representation of First Nations art in Queensland. This tension between institutions and their understanding of First Nations arts and how individuals conceptualize themselves as artists comes about in part due to a lack of recognition of the historical underpinnings working on the industry today. In Dreamings, Sutton comments on the barriers to the reception of Aboriginal art and writes, 'Whether it was because of their rarity, the abstruseness of their culture of origin, or the low esteem in which their makers were held, Australian Aboriginal works in the past failed to capture the attention of the European and North American art world' (Sutton 1989: 34). Hints of this engagement can be found in Roman Black's book, Old and New Australian Aboriginal Art (1964).

Roman Black's Old and New Australian Aboriginal Art is an intriguing take on 'Aboriginal' art. Old Aboriginal art, according to Black, is that art which might be conceived of as 'traditional. This includes shields, bark paintings, rock art galleries, engraved baobab nuts, tree carvings, spears and boomerangs. The first two-thirds of the book are devoted to such items. Black's goal is to create a general sense of what 'old' Aboriginal art is. For example, Black writes the churingas of Western Australia are typified by 'longitudinal zig-zags, concentric squares, rhomboids, lozenges, triangles, herring-bone, and angular meanders' (Black 1964: 36). Black's work is surprisingly detailed in those things he chooses to highlight as 'old' Aboriginal art.

The last third of Black's book focuses on 'new' Aboriginal art and this art is defined by Black as art which is based on 'old' Aboriginal art but produced by white Australians. Of particular interest to Black is Margaret Preston's works. In showing her a piece of African art, Black quotes Preston as saying it was 'wrong' because 'it's not primitive enough. It is too civilised' (Black 1964: 125). Her call then to look to Aboriginal artworks for inspiration is based on the legitimization of First Nations culture as primitive 'enough'. Other artists Black explores include Douglas Annand, Bryam Mansell and Gert Sellheim (Black 1964: 12638). Bryam Mansell's work is noteworthy and praised by Black because of his incorporation and invention of Aboriginal myths to go with his paintings of Aboriginal themes (Black 1964: 136-7). There is also some discussion on William Constable's Corroboree, 'The Fire Ceremony' dance. Black emphasizes the importance of white artists and the incorporation of Aboriginal motifs in their artworks - he calls this 'applied Aboriginal art' (Black 1964: 147).

The importance of Black's book is not just because of the attempt to develop an Aboriginal art history but because of what this book says about 
public expectations of Aboriginal art. Black's book was published in 1964, five years after the development of Queensland Aboriginal Creations (QAC), the Brisbane-based curio shop supporting various cottage industries across the state of Queensland. This book helps not only illustrate how Aboriginal fine art was able to make it into the public sphere but also illustrates how the stereotyping of Aboriginal art began to seep into the public consciousness.

Chris Healy's Forgetting Aborigines (2008) discusses Aboriginal art during this early time period as well. Using the concepts of 'Abo Art' ${ }^{8}$ and 'Aboriginal' art produced by white artists, Healy explores how Aboriginal art produced a type of forgetfulness with regard to the cultural copyright violations of white artists using Aboriginal motifs (Healy 2008: 68). Referencing Black's book, Healy examines the 'ambivalent culture space of Aboriginality' which existed for a long time with regard to artistic production (Healy 2008: 69). Specifically, Healy argues that the remembering of Papunya as the beginnings of Aboriginal art is a process of forgetting the histories before those events and the market for Aboriginal kitsch and 'Abo Art' (Healy 2008: 72). For Black, according to Healy, old Aboriginal art was pre-contact: rock engravings, bark paintings, and so on while new Aboriginal art was art practised by white mainstream artists in an 'Aboriginal' style (Healy 2008: 79). Healy uses the term 'Abo Art' deliberately with this form of art production to both incite a reaction and to label forms such as Aboriginalia, Aboriginal kitsch, and 'fine art' inspired by Aboriginal motifs and styles (Healy 2008: 80). First Nations people were excluded from the high art category, and it was a necessary disappearance in order for their motifs to be used. In this way, the mining of Aboriginal art was used to 'localise settler culture' to a wider audience (Healy 2008: 84). Healy makes the radical conclusion that by forgetting Abo Art and focusing on Papunya as the source of Aboriginal art today, the art historical significances of Abo Art are ignored. According to Healy, Abo Art paved the way for modern art practices to be accepted and/or even looked at (Healy 2008: 89).

The history of First Nations art in Queensland is pocketed across different publications with different degrees of detail. There are two catalogues of particular interest, published by the Queensland Government and Keeaira Press, which draw attention to First Nations artists in Queensland. The first catalogue was called Gatherings: Contemporary Aboriginal and Torres Strait Islander Art from Queensland Australia and was compiled by Marion Demozay and an allIndigenous reference panel (2001). It included a very small introduction essay about the project as a whole but many full-colour images of artworks with small bios of the artists who created them. The first Gatherings was very popular and 
prompted interest in another volume. In Gatherings II: Contemporary Aboriginal and Torres Strait Islander Art from Queensland Australia, Marion Demozay wrote a more extensive introductory essay which explores the early history of art, craft and curio production in Queensland (2006). It is one of the most comprehensive attempts at such a history. In her introduction, Demozay mentions QAC and the TAFE First Nations arts programme as key actors in the development of the arts industry in Queensland (2006: 32).

Additionally, according to Demozay, 'another major contribution towards the long-overdue recognition of Queensland's First Nations art and its history was the Queensland Art Gallery's 2003 initiative the Story Place: Indigenous Art of Cape York and the Rainforest, the first major exhibition to explore the historical and contemporary art of Cape York's First Nations peoples' (Demozay 2006: 11). Indeed, Story Place attempts to cover the entire ground of Aboriginal art history in Queensland and includes a wide range of articles covering aspects such as not only the history of the TAFE programme and QAC but also the people of Cape York, the history of collecting, basketry and weaving, as well as profiles of major artists and movements. The art historian Sally Butler included a few well-written but short paragraphs about the beginnings of QAC in her essay 'Cape York's Time in Motion' (Butler 2003). Butler cites the role of Queensland tourism industry as key in the development of First Nations art production in the Cape. This resulted in people being 'ignorant of any cultural context of the visual material and uncertain whether items were art, artefact or trinket' (Butler 2003: 196). However, it is my contention that despite extensive collecting, history has been written with pockets of forgetfulness and the true story of Queensland First Nations art history has been blurred and generalized to the point of being destructive rather than constructive.

I spent a year inside the Cairns TAFE studio, working with the artists and instructors. To say I was simply an observer would be misleading although I did record the activities in the studio. I was also hired as a studio assistant a month after the term started. I taught colour mixing and produced a few lectures on Western art history as requested by the lead instructor. I was also encouraged to participate in the painting and printing units which allowed me to understand the processes of art production as well as the learning techniques employed to pass on these processes. Because of my own Indigeneity, I was frequently encouraged to produce works which reflected my heritage and was frequently teased when these works did not meet expectations. Beyond participant observation, I conducted a number of structured interviews and personal histories of students in order to gauge their perceptions of the studio and of 
themselves. I also conducted research outside of the studio by attending the art markets, gallery openings, dance performances and cultural fairs which are a part of life in Cairns for Aboriginal and Islander peoples.

New understandings about the nature of Aboriginal and Torres Strait Islander art are drawn out and detailed. For the first time, a complete outline of the historical underpinnings of the First Nations art market in Queensland is laid out alongside the development of the Aboriginal and Torres Strait Islander arts school in Cairns. This development is told by past and present participants through one-on-one interviews. Finally, there will be a detailed account and analysis of the types of motifs and styles of Aboriginal and Torres Strait Islander artworks, making clear the points of contrast between the two First Nations groups.

Aboriginal and Torres Strait Islander art students engaging in formal training for the first time are stepping into a quagmire of identity politics, colonialist histories and inter-/intracultural struggles. Within the art world of First Nations Australia is a hierarchy of categories and intercultural spaces where culture is both produced and reproduced, contested and dictated. Engaging with the First Nations art market means taking on board and struggling with a range of assumptions and expectations on one's identity and modes of cultural (re)production.

To break the stereotypes of First Nations art in Australia, the relationship between artists and their chosen motifs and a clear documentation of what design elements and motifs are utilized needs to be understood. The potential factors determining these choices make up the legacy of Queensland's art policies as well as artists' conceptions of self. Artists choose to paint those things that matter to them. How things matter and what is painted is explored in detail.

The art produced by Aboriginal and Torres Strait Islander students going through the TAFE studio was found to be determined and framed by four factors: (1) the history of the First Nations arts industry in Queensland; (2) the curriculum within the studio; (3) experiences with the markets and galleries; and (4) students' personal histories. The First Nations arts studio at the North Queensland Institute of TAFE in Cairns is a unique space where First Nations instructors teach First Nations students about First Nations art. This raises a host of questions about the process of teaching culture, conceptions and expectations about First Nations artistic practices and the engagement of students with the curriculum, the tourist art market and local art galleries. The arts studio is the nexus - a seemingly bounded and yet unbounded space - where the 
development of Queensland art production, the history of colonial regimes and popular perceptions about the First Nations art market all play out.

\section{Notes}

1 As of 2017, Cairns' largest industry is the health care and social services sector. See https://www.cairns.qld.gov.au/region/facts (accessed 24 October 2018).

2 For a brief and accessible account of this movement, see the National Museum of Australia’s 'Defining Moment' synopsis, https://www.nma.gov.au/defining-moments/ resources/papunya-tula (accessed 19 June 2019).

3 Bob Katter (2018). 'Indonesian "Aboriginal” art ripping off First Australians' https:// www.bobkatter.com.au/module/latestNews/view/935/indonesian-aboriginal-artripping-off-first-australians-/media-releases (accessed 20 September 2018).

4 Angus Thompson (2018). 'ACCC launches legal action over "Indonesian made" Aboriginal art' https://www.smh.com.au/business/consumer-affairs/accc-launcheslegal-action-over-indonesian-made-aboriginal-art-20180322-p4z5r5.html (accessed 20 September 2018).

5 Stephen Stockwell (2018). “"A bloody lot” of fake Indigenous art is being sold. Here's how you can spot it' http://www.abc.net.au/triplej/programs/hack/how-to-spot-fakeindigenous-art/9817052 (accessed 20 September 2018).

6 Transcript from unpublished lecture during the Cairns Indigenous Art Fair Symposium, 18 August 2011. Used with permission.

7 Importantly, UMI has no facilities for art production aside from their classes. Unlike the descriptions of art centre practices by researchers like Altman $(1990,2005)$ and Wright and Morphy (2000), art production in Cairns is done at home where artists are responsible for supplying their own materials. This is a crucial distinction when comparing art centres in very remote areas to UMI Arts as the support structures provided to artists are radically different.

8 This term is generally regarded as highly offensive but was used historically in several contexts as this section discusses. It is being used in this book as Healy uses it and is not condoned by the author in any way.

1 This is the historical title used in Queensland during this time and technically also included Torres Strait Islanders. Today, 'Aborigines' is considered by many First Nations peoples as no longer appropriate. Some even find it offensive. The preferred terms today are 'Aboriginal peoples' or specific tribal affiliations (e.g. Yidinji, Noongar, pakana).

2 Queensland State Archives Item ID336275, Correspondence, Aboriginal and Torres Strait Islander. Further details: Curios 1179/1933-4442/1933, summary of multiple letters of correspondence. 
3 Ibid.

4 Queensland State Archives Item ID336275, Correspondence, Aboriginal and Torres Strait Islander. Further details: Queensland Tourist Bureau's itemized inventory sheet, September 1933.

5 Queensland State Archives Item ID336275, Correspondence, Aboriginal and Torres Strait Islander. Further details: 19 December 1933 memorandum from J. W. Bleakley to the Protector Thursday Island.

6 Queensland State Archives Item ID336275, Correspondence, Aboriginal and Torres Strait Islander. Further details: 27 April 1933 letter from J. W. Bleakley to Cherbourg settlement.

7 Queensland State Archives Item ID336275, Correspondence, Aboriginal and Torres Strait Islander. Further details: 27 April 1933 letter from J. W. Bleakley to Cherbourg's superintendent.

8 Queensland State Archives Item ID336275, Correspondence, Aboriginal and Torres Strait Islander. Further details: 6 June 1933 letter from J. W. Bleakley to Palm Island's superintendent.

9 Queensland State Archives Item ID336666 and Item ID336929, Correspondence, Aboriginal and Torres Strait Islander. Further details: summary of multiple letters of correspondence across both files. See particularly a letter from the Mexican Consul for 'certain Australian novelties suitable for gift purposes' dated 5 April 1939.

10 Queensland State Archives Item ID336275, Correspondence, Aboriginal and Torres Strait Islander. Further details: September 1933 letter from J. W. Bleakley to Yarrabah's superintendent.

11 Queensland State Archives Item ID336275, Correspondence, Aboriginal and Torres Strait Islander. Further details: summary of multiple letters of correspondence.

12 Queensland State Archives Item ID336277, Correspondence, Aboriginal and Torres Strait Islander. Further details: record has several examples of correspondences between the Chief Protector and communities outlining the process of sale and reimbursement and the tracking of individuals.

13 Queensland State Archives Item ID336275, Correspondence, Aboriginal and Torres Strait Islander. Further details: 27 October 1933 memorandum from the Deputy Chief Protector of Aboriginals to Cherbourg's superintendent.

14 Today, museums selling mass-produced items in their gallery stores are moving towards naming the artist and away from works without producer names. The National Museum of Australia in Canberra is a good example of this emerging practice.

15 Queensland State Archives Item ID336276, Correspondence, Aboriginal and Torres Strait Islander. Further details: 29 September 1933 letter from the captain of the Ulysses to the chief protector. 
16 Queensland State Archives Item ID336276, Correspondence, Aboriginal and Torres Strait Islander. Further details: 24 March 1933 letter from the captain of the Manunda to the chief protector.

17 Queensland State Archives Item ID336661, Correspondence, Aboriginal and Torres Strait Islander. Further details: 28 June 1935 Telegraph newspaper article.

18 Queensland State Archives Item ID336661, Correspondence, Aboriginal and Torres Strait Islander. Further details: 14 August 1935 Telegraph newspaper article.

19 Queensland State Archives Item ID336280, Correspondence, Aboriginal and Torres Strait Islander. Further details: undated schedule of items for display at the Brisbane exhibition.

20 Queensland State Archives Item ID336661, Correspondence, Aboriginal and Torres Strait Islander. Further details: 28 June 1935 Telegraph newspaper article.

21 Queensland State Archives Item ID336661, Correspondence, Aboriginal and Torres Strait Islander. Further details: 9 July 1935 memorandum from the deputy chief protector to the Government Printer, Brisbane.

22 Queensland State Archives Item ID336661, Correspondence, Aboriginal and Torres Strait Islander. Further details: 24 August 1935 newspaper article from The Telegraph.

23 Queensland State Archives Item ID502315, Correspondence, Aboriginal and Torres Strait Islander. Further details: 17 August 1935 newspaper article from The Telegraph.

24 Babcock is citing O. S. Halseth (1925) 'The Acculturation of the Pueblo'. El Palacio 18:12, 263-4.

25 Queensland State Archives Item ID502314, Correspondence, Aboriginal and Torres Strait Islander. Further details: 19 December 1959 report from H. R. Pascoe to the chief protector.

26 Queensland State Archives Item ID502314, Correspondence, Aboriginal and Torres Strait Islander. Further details: 15 January 1959 report from H. R. Pascoe to the chief protector.

27 Queensland State Archives Item ID502314, Correspondence, Aboriginal and Torres Strait Islander. Further details: 9 February 1959 letter from the director of Native Affairs to the undersecretary.

28 Queensland State Archives Item ID502314, Correspondence, Aboriginal and Torres Strait Islander. Further details: 20 March 1959 letter from H. R. Pascoe to the chief protector.

29 Queensland State Archives Item ID502314, Correspondence, Aboriginal and Torres Strait Islander. Further details: 28 November 1958 newsletter published by the Public Relations Bureau, Brisbane.

30 Queensland State Archives Item ID502314, Correspondence, Aboriginal and Torres Strait Islander. Further details: 1 December 1958 memorandum from H. R. Pascoe to the chief protector. 
31 Queensland State Archives Item ID502314, Correspondence, Aboriginal and Torres Strait Islander. Further details: 28 September 1959 memorandum from H. R. Pascoe to the Department of Native Affairs.

32 Queensland State Archives Item ID502314, Correspondence, Aboriginal and Torres Strait Islander. Further details: 2 September 1959 memorandum for the files.

33 Queensland State Archives Item ID502314, Correspondence, Aboriginal and Torres Strait Islander. Further details: 30 July 1959 letter to the director, QAC.

34 Queensland State Archives Item ID502314, Correspondence, Aboriginal and Torres Strait Islander.

35 Queensland State Archives Item ID502315, Correspondence, Aboriginal and Torres Strait Islander. Further details: 31 August 1960 letter from Currumbin Tea Gardens to Queensland Aboriginal Creations.

36 The records do little to illuminate why there was a restructuring. Further research needs to be done to see if there was any political or economic reason for such a move.

37 Queensland State Archives Item ID504819, Correspondence, Aboriginal and Torres Strait Islander. Further details: 26 April 1967 letter from A. V. Istead (director of QAC) to the director, Aboriginal and Islander Affairs.

38 Queensland State Archives Item ID646454, Correspondence, Aboriginal and Torres Strait Islander. Further details: 19 March 1986 order form from Arnhem Art to QAC.

39 Queensland State Archives Item ID646444, Correspondence, Aboriginal and Torres Strait Islander. Further details: 5 March 1968 letter from I. V. Istead to the Hope Vale manager.

40 Personal communication, 1 September 2011.

41 Aird's publication has several photos which illustrate this period and is well worth exploring for further context.

42 Queensland State Archives Item ID504813, Correspondence, Aboriginal and Torres Strait Islander. Further details: 1 July 1969 invoice from Australian Aboriginal Creations to QAC.

43 Queensland State Archives Item ID511249, Correspondence, Aboriginal and Torres Strait Islander. Further details: for one of many examples, see 16 August 1983 letter from Peter McMahon to Sir Sydney Williams, OBE.

44 Queensland State Archives Item ID511249, Correspondence, Aboriginal and Torres Strait Islander. Further details: 20 June 1983 letter from QAC to Australia Council.

45 Queensland State Archives Item ID336275, Correspondence, Aboriginal and Torres Strait Islander. Further details: 23 November 1932 letter from J. W. Bleakley to Cherbourg superintendent.

46 Queensland State Archives Item ID646444, Correspondence, Aboriginal and Torres Strait Islander. Further details: 25 September 1968 letter from QAC to Hope Vale superintendent. 
47 Queensland State Archives Item ID502316, Correspondence, Aboriginal and Torres Strait Islander. Further details: 20 September 1961 letter from J. W. Bleakley to A. W. C. de Witte, manager at Karumba Lodge.

48 Queensland State Archives Item ID336663, Correspondence, Aboriginal and Torres Strait Islander. Further details: 30 July 1937 letter from J. W. Bleakley to Woorabinda superintendent.

49 Queensland State Archives Item ID336663, Correspondence, Aboriginal and Torres Strait Islander. Further details: 30 July 1937 letter from J. W. Bleakley to Cherbourg superintendent.

50 Queensland State Archives Item ID646417, Correspondence, Aboriginal and Torres Strait Islander. Further details: 7 June 1984 letter from Huggy Bear Beamers to QAC.

51 Personal communication, 11 October 2011.

52 Ibid.

53 Queensland State Archives Item ID646421, Correspondence, Aboriginal and Torres Strait Islander. Further details: 24 December 1991 letter from John Conroy to Aboriginal Arts Management Association, Inc.

54 Queensland State Archives Item ID646421, Correspondence, Aboriginal and Torres Strait Islander. Further details: 22 January 1992 letter from Aboriginal Arts Management Association, Inc. to John Conroy/QAC.

55 Queensland State Archives Item ID646421, Correspondence, Aboriginal and Torres Strait Islander. Further details: 22 January 1992 letter from Aboriginal Arts Management Association, Inc. to John Conroy/QAC.

56 Queensland State Archives Item ID646421, Correspondence, Aboriginal and Torres Strait Islander. Further details: 22 January 1992 letter from Aboriginal Arts Management Association, Inc. to John Conroy/QAC.

57 Koori and Murri are colloquial terms for a collective Aboriginal identity. Koori are those Aboriginal people in southern states such as New South Wales and Victoria. Murri are those Aboriginal people across the entire state of Queensland.

58 Queensland State Archives Item ID646421, Correspondence, Aboriginal and Torres Strait Islander. Further details: 22 January 1992 letter from Aboriginal Arts Management Association, Inc. to John Conroy/QAC.

59 Personal communication, 1 September 2011.

60 Personal communication, 11 October 2011.

61 Personal communication, 1 September 2011.

62 Ibid.

63 Ibid.

64 Queensland State Archives Item ID646421, Correspondence, Aboriginal and Torres Strait Islander. Further details: 6 December 1991 letter from Richard Bell to Les Malezer/Department of Family Services and Aboriginal Affairs, Brisbane, Queensland. 
65 Personal communication, 1 September 2011.

1 The arrival of non-Indigenous people to Australia is obviously a very contentious issue. For many First Nations peoples, this day is called Invasion Day. For non-Indigenous Australians, it's called the arrival of the First Fleet and is a day to celebrate. Further discussion of this polarizing topic is beyond the scope of this book to address.

2 Queensland State Archives Item ID646441, Correspondence, Aboriginal and Torres Strait Islander. Further details: 15 May 1992 letter from John Conroy to Mr J. Burless, executive officer, Welfare Services Branch.

3 In today's spelling, it is considered respectfully appropriate to capitalize Indigenous when referring to First Nations peoples.

4 Queensland State Archives Item ID642197, Correspondence, Aboriginal and Torres Strait Islander. Further details: the file folders contained all the course outlines for 1983-4 and were all labelled as from the 'Officer-in-Charge Aboriginal and Islander TAFE services'.

5 Queensland State Archives Item ID642197, Correspondence, Aboriginal and Torres Strait Islander. Further details: course outline signed off on 25 October 1983.

6 Queensland State Archives Item ID642197, Correspondence, Aboriginal and Torres Strait Islander. Further details: course outline signed off on 14 November 1983.

7 Queensland State Archives Item ID642197, Correspondence, Aboriginal and Torres Strait Islander. Further details: course outline signed off on 8 June 1983.

8 Queensland State Archives Item ID642197, Correspondence, Aboriginal and Torres Strait Islander. Further details: course outline signed off on 1 November 1983.

9 Queensland State Archives Item ID642197, Correspondence, Aboriginal and Torres Strait Islander. Further details: course outline signed off but undated. Course noted to commence 3 October 1983.

10 Personal communication, 22 September 2010.

11 Ibid.

12 Personal communication, 15 June 2010.

13 Ibid.

14 Personal communication, 21 September 2010.

15 Ibid.

16 Ibid.

17 Personal communication, 22 September 2010.

18 Ibid.

19 Personal communication, 14 December 2010.

20 Ibid.

21 Personal communication, 21 May 2010.

22 Compared to the intense legal and insurance documentation required to book such transport during the 2010 field period, even a trip to the Cairns Art Gallery was often fraught with bureaucratic red tape. 
23 Anna Eglitis, personal communication, 14 December 2010.

24 Ibid.

25 Ibid.

26 Queensland State Archives Item ID646409, Correspondence, Aboriginal and Torres Strait Islander. Further details: meeting minutes from 11 and 12 February 1992. This item number at the Queensland State Archives contains a huge amount of data on the development of the Cairns ATSI arts course - not all of which can be included in this chapter.

27 Ibid.

28 Queensland State Archives Item ID646409, Correspondence, Aboriginal and Torres Strait Islander. Further details: meeting minutes from 11 and 12 February 1992.

29 Queensland State Archives Item ID646409, Correspondence, Aboriginal and Torres Strait Islander. Further details: Coursework matrix from 22 June 1992, included in the meeting minutes from 11 September 1992.

30 Ibid.

31 Queensland State Archives Item ID646409, Correspondence, Aboriginal and Torres Strait Islander. Further details: meeting minutes 11 and 12 February 1992. Original emphasis.

32 Queensland State Archives Item ID646409, Correspondence, Aboriginal and Torres Strait Islander. Further details: meeting minutes 11 and 12 February 1992.

33 Queensland State Archives Item ID646409, Correspondence, Aboriginal and Torres Strait Islander. Further details: meeting minutes 11 September 1992.

34 Personal communication, 14 December 2010.

35 Personal communication, 21 May 2010.

36 Personal communication, 15 June 2010.

1 Personal communication, 29 October 2010.

2 Personal communication, 31 August 2010.

3 Curiously, this is the only restriction that was placed on me with regard to talking about artistic protocols. Most of the time, processes and information were shared freely with the hopes of educating 'people in Canberra'.

4 Personal communication, 29 October 2010.

5 Department of Human Services (2016). https://www.humanservices.gov.au/ corporate/about-us (accessed 25 June 2017). Last updated 8 December 2016.

6 Personal communication, 29 October 2010.

7 Personal communication, 7 April 2010.

8 CDEP (Community Development Employment Projects) is a type of work for the dole programme encouraging Indigenous employment. See Sanders (1993) and Gray et al. (2013).

9 Personal communication, 14 October 2010.

10 Personal communication, 5 November 2010. 
11 Personal communication, 2 September 2010.

12 Personal communication, 29 October 2010.

13 Personal communication, 2 September 2010.

14 Personal communication, 7 April 2010.

15 Personal communication, 21 June 2010.

16 Personal communication, 14 October 2010.

17 Personal communication, 2 September 2010.

18 Personal communication, 29 October 2010.

19 Personal communication, 3 April 2010.

1 Personal communication, 1 June 2010.

2 Personal communication, 22 August 2010.

3 Within the traditional shield designs, the triangular notches radiating away from the central diamond within the shield are similar to the notches found on the region's scorpion's head.

4 Personal communication, 5 November 2010.

5 Personal communication, 29 October 2010.

6 New King James, Matthew 13:31-32 tells the parable of the mustard seed: 'The kingdom of heaven is like a mustard seed, which a man took and sowed in his field, which indeed is the least of all the seeds; but when it is grown it is greater than the herbs and becomes a tree, so that the birds of the air come and nest in its branches.'

7 Art studios never use the term 'purple'.

8 As a side note, this engagement is a very different way of providing one's credentials compared to the previous discussion. By bringing in terms such as 'diffusionist ideology' and Bauhaus colour theory, Richard was creating a very different type of authority.

9 Personal communication, 15 June 2010.

1 Personal communication, 29 October 2010.

2 In order to protect the privacy and reputation of this person today, a pseudonym is used.

3 In bead working circles, 'seed beads' generally mean small glass beads produced in either Czechoslovakia or Japan. The term 'seed beads' in the field referred to beads made of plant seeds which were harvested wild and treated in the studio.

4 Cairns also sets up weekend markets along the esplanade which is less regulated than the Port Douglas markets in content. Seed bead jewellery sold there is also by a non-Indigenous stall owner but the managers do not limit the people involved and so Michelle has occasionally set up a booth during weekends she feels there are enough tourists and substantial crowds to make it worth her while. The Cairns weekend markets have intermittent involvement by Indigenous people who set up stalls to sell their paintings, boomerangs or jewellery.

5 Personal communication, 12 July 2018. 
6 Erin is a pseudonym.

1 Bell's ground-breaking essay is available online: http://wag.com.au/ files/9113/3342/7328/WhyYouPaintLikeThatEssay.pdf (accessed 1 November 2019) and is highly recommended for further reading.

2 It is obvious from the onset of this method that not all artists produced an equal amount of works; the production rate of each artist varied considerably. For example, one single artist produced over sixty-five images during the course of the year within the studio alone. (He produced dozens more outside the studio which are not included in the content analysis.) On the other hand, quite a few students produced less than ten works during the same time period. The 420 artworks were evaluated based on a series of 34 questions which were recorded in an Excel spreadsheet. In order to avoid a single artist skewing the content analysis results, statistical weighting was applied to each image. In this instance, a statistical weight is a number assigned to an image which gives the relative frequency of the attribute in question. In order to calculate a statistical weight, each artist's total production value equalled one which was then divided by the total works produced. For example, an artist producing fifteen works had a statistical weight of 0.066 assigned to each artwork he or she produced; an artist producing twenty-one works had a statistical weight of 0.047 . This statistical weighting gives a relative value to each image so that when viewing the results, an equal relational comparison between all works is created. In this way, each image is 'equal' in relation to the other images produced. There are two issues with this type of weighting. First, there is the question of personal meaning in artworks. Artists who only produce four works with a statistical weight of 0.250 - are considered the same as artists who produce much, much more. There are a couple of considerations I am taking which help alleviate this issue. Looking at the overall results, the few cases of extremely low producers do not influence the outcomes negatively and, indeed, simply reinforce the overall trend or story the content analysis is telling. Additionally, only four assignments dictated specific motifs in an artwork (such as self-portraits). On the whole, assignments were very open-ended with regard to content. With this in mind, I feel sure that the artworks which the low producers created are as valuable to the study as the rest of the works. The second issue caused by using statistical weighting is that despite this modification, there are still some over-producers who do influence the results. These cases are noted in the analysis.

3 Howard Morphy, personal communication, 1 August 2012.

1 Personal communication, 14 October 2010.

2 Ibid.

3 Personal communication, 17 July 2018.

4 Ibid.

5 Ibid. 
6 That some Islanders learn their cultural heritage through books should never be taken as these Islander people being 'less' but, rather, should be viewed as the results of violent colonial contact, displacement and a legacy of draconian policies heaped upon Islanders. Creating hierarchies of 'real'/'unreal', 'authentic'/'inauthentic' and 'traditional'/'non-traditional' feed into colonial narratives of erasure and should be avoided.

7 Personal communication, 10 April 2010.

8 Personal communication, 22 August 2011.

9 Ibid.

10 Ibid.

11 Personal communication, 2 May 2014.

12 Typed handout, authored by Tommy, dated August 2010.

13 Personal communication, 29 April 2011.

14 Tommy Pau, personal communication, 22 August 2010.

15 Billy Missi, personal communication, 10 April 2010.

16 Personal communication, 13 July 2010.

17 Spellings for these islands are taken from Sharp (1992: Map 1).

18 Personal communication, 13 July 2010, emphasis added.

1 The pop-up galleries were available due to the Cairns Regional Council's Beautiful Spaces programme - a programme which facilitates the use of retail and office spaces left unoccupied for temporary shops in order to keep the downtown area viable. For more information see http://www.cairns.qld.gov.au/facilities-andrecreation/arts-culture/beautiful-spaces (accessed 29 January 2013).

2 Personal communication, 12 July 2019.

3 Speech excerpt 23 November 2012. Used with permission. 


\section{Bibliography}

AIATSIS (2017), 'Torres Strait Islander Flag', Australian Institute for Aboriginal and Torres Strait Islander Studies. Available online: https://aiatsis.gov.au/explore/articles/ torres-strait-islander-flag (accessed 29 October 2018).

Aird, M. (1993), Portraits of Our Elders, Brisbane: Queensland Museum.

Aird, M. (2001), Brisbane Blacks, Southport: Keeaira Press.

Alfonso, C., and M. Kershaw, eds (2001), Gelam Nguzu Kazi - Dugong My Son, Brisbane: Kubin Community Council.

Allen, L. (2003), 'A History of Collecting Indigenous Artefacts in North Queensland', in Queensland Art Gallery (ed.), Story Place: Indigenous Art of Cape York and the Rainforest, 30-43, South Brisbane, QL: Queensland Art Gallery.

Allen, L. (2008), 'Tons and Tons of Valuable Material: The Donald Thompson Collection', in N. Peterson, L. Allen and L. Hamby (eds), The Makers and Making of Indigenous Australian Museum Collections, 387-418, Melbourne: Melbourne University Press.

Altman, J. and L. Taylor, eds (1990), Marketing Aboriginal Art in the 1990s, Canberra: Aboriginal Studies Press.

Altman, J., B. Hunter, S. Ward and F. Wright (2002), 'Some Competition and Consumer Issues in the Indigenous Visual Arts Industry', Centre for Aboriginal Economic Policy Research, CAEPR Discussion Paper No. 235, Canberra: CAEPR.

Anderson, S. (2001), 'The Aboriginal Art Industry in Cairns, Queensland: An Ethnograhic Study', PhD diss., School of Archaeology and Anthropology, The Australian National University, Canberra.

Aristides, J. (2008), Classical Painting Atelier: A Contemporary Guide to Traditional Studio Practices, New York: Watson-Guptill.

Australian Bureau of Statistics (2012), 'Census of Population and Housing - Counts of Aboriginal and Torres Strait Islander Australians, 2011', http://www.abs.gov.au/ ausstats/abs@.nsf/Lookup/2075.0main+features32011 (accessed 1 September 2012).

Babcock, B. (1995), 'Marketing Maria: The Tribal Artist in the Age of Mechanical Reproduction', in Brenda Jo Bright and Liza Bakewell (eds), Looking High and Low, 124-50, Tuscan: University of Arizona Press.

Baker, A. (2008), Aurukun Artists: Wiy Min Yumpan Ngamp, Cairns: Japingka Gallery. Barrow, T. (1978), Maori Art of New Zealand, Paris, UNESCO Press.

Bayer, H., W. Gropius and I. Gropius, eds (1975), Bauhaus: 1919-1928, London: Secker \& Warburg.

Beckett, J. (1987), Torres Strait Islanders: Custom and Colonialism, Cambridge: Cambridge University Press.

Beckett, J., ed. (1994), Past and Present: The Construction of Aboriginality, Canberra: Aboriginal Studies Press. 
Bell, M. (2010), Why You Paint Like That, Brisbane: Woolloongabba Art Gallery.

Bell, M. (2012), You Can Do That or What?, Brisbane: Woolloongabba Art Gallery.

Bell, R. (2002), 'Bell's Theorem: Aboriginal Art - It's a White Thing!'. Available online: http://www.kooriweb.org/foley/great/art/bell.html (accessed 2 May 2008).

Belting, H. (2011), An Anthropology of Images: Picture, Medium, Body, trans. T. Dunlap, Princeton, NJ: Princeton University Press.

Bennett, T. (2015), 'Cultural Studies and the Culture Concept', Cultural Studies 29, no. 4: 546-68.

Biddle, J. (2007), Breasts, Bodies, Canvas: Central Desert Art as Experience, Sydney: University of New South Wales Press.

Birren, F. (1970), The Elements of Colour: A Treatise on the Colour System of Johannes Itten, New York: Van Nostrand Reinhold.

Black, R. (1964), Old and New Australian Aboriginal Art, Sydney: Halstead Press.

Bleakley, J. W. (1935), 'The Aborigines: Past and Present Treatment by the State', in J. S. Needham (ed.), White and Black in Australia, 38-48, London: National Missionary Council of Australia.

Bleakley, J. W. (1961), The Aborigines of Australia: Their History, Their Habits, Their Assimilation, Brisbane: Jacaranda Press.

Bottoms, T. (1990), Djarrugan, the Last of the Nesting, MA diss., James Cook University, Townsville.

Bottoms, T. (1999), Djabugay Country: An Aboriginal History of Tropical North Queensland, Cairns, St Leondards Allen \& Uwin.

Bottoms, T. (2002), A History of Cairns: City of the South Pacific (1770-1995), PhD diss, School of Humanities, Faculty of Arts, Health and Science, Central Queensland University, Cairns.

Brinkman, P., ed. (2010), Malu Minar [Sea Pattern]: Art of the Torres Strait, Cairns: Cairns Regional Gallery.

Burton, H. K. (1936), The Re-Establishment of the Indians in Their Pueblo Life through the Revival of Their Traditional Crafts: A Study in Home Extension Education, New York, Teachers College, Columbia University.

Butler, S. (2003), 'Cape York's Time in Motion', in Queensland Art Gallery (ed.), Story Place: Indigenous Art of Cape York and the Rainforest, 192-9, South Brisbane, QL: Queensland Art Gallery.

Cairns Regional Council (2010a), 'Which Industries Employ People? Employment by Industry'. Available online: http://economy.id.com.au/default. aspx?id=363\&pg=12310 (accessed 5 December 2012).

Callow, D. (2010), Bipotaim: Stories from the Torres Strait, Thursday Island: Gab Titui Cultural Centre.

Canopy Artspace (2009a), 'Organisations - AAN Network'. Available online: http:// www.canopyarts.com/about_aapn.php (accessed 29 August 2012).

Canopy Artspace (2009b), 'Organisations - Editions Tremblay NFP'. Available online: http://www.canopyarts.com/about_aapn.php (accessed 29 August 2012). 
Carty, J. (2011), 'Creating Country: Abstraction, Economics and the Social Life of Style in Balgo Art', PhD diss., Research School of the Humanities, the Australian National University, Canberra.

Caruana, W. (2000), 'Black Art on White Walls? Institutional Responses to Aboriginal Art' in S. Kleinert and M. Neal (eds), The Oxford Companion to Aboriginal Art and Culture, 454-60, Oxford: Oxford University Press.

Cecilia, A., and M. Kershaw, eds (2001), Gelam Nguzu Kazi - Dugong My Son, Brisbane: Kubin Community Council.

Chute, H. (2010), Graphic Women: Life Narrative and Contemporary Comics, New York: Columbia University Press.

Coates, K. S. (2004), A Global History of Indigenous Peoples: Struggle and Survival, New York: Palgrave Macmillan.

Coleman, E. B. (2001), 'Aboriginal Painting: Identity and Authenticity', The Journal of Aesthetics and Art Criticism 59: 385-402.

Coleman, E. B. (2005), Aboriginal Art, Identity and Appropriation, England: Ashgate.

Collingwood, R. G. ([1958] 2003), 'Good Art and Bad Art', in C. Harrison and P. Wood (eds), Art in Theory - 1900-2000: An Anthology of Changing Ideas, 536-9, Carlton: Blackwell.

Cooper, C. (1989), Aboriginal and Torres Strait Islander Collections in Overseas Museums, Canberra: Aboriginal Studies Press.

Dalton, N. (2011), 'Visitor Numbers Up at Cairns Airport', Monday, 22 August. Available online: http://www.cairns.com.au/article/2011/08/22/179145_local-news. html (accessed 16 October 2012).

Demozay, M. (2001), Gatherings: Contemporary Aboriginal and Torres Strait Islander Art from Queensland, Australia, Southport Queensland: Keeaira Press.

Demozay, M. (2006), Gatherings II: Contemporary Aboriginal and Torres Strait Islander Art from Queensland, Australia, Southport Queensland: Keeaira Press.

Dixon, G. (2008), On the Edge: Visions of a Tropical Coastline, Cairns: On the Edge Collective.

Edmund, M. (1990), 'Vocational Arts Centre Cairns', Artlink, 1 and 2: 109.

Eglitis, A. (1990), 'Artistic Technique Training at Cairns Tafe', in J. Altman and

L. Taylor (eds), Marketing Aboriginal Art in the 1990s, 83-8, Canberra:

Aboriginal Studies Press.

Eglitis, A., ed. (2000), Contemporary Aboriginal and Torres Strait Islander Art: Now

Days - Early Days, Rockhampton: Central Queensland Press.

Eglitis, A., and W. Brim (2005), Creatures of the Rainforest: Two Artists Explore

Djabugay Country, Broome: Magabala Books Aboriginal Corporation.

Eglitis, A., and P. Henderson (1991), 'Aboriginal \& Islander Art Course More Than

Survival', Artlink, 3: 19-21.

Erickson, A., and L. Murphy (2003), A History of Anthropological Theory, Orchard Park, NY: Broadview Press. 
Evans, R. (1979), Bleakley, John William (1879-1957). Available online: http://adb.anu. edu.au/biography/bleakley-john-william-5272/text8887 (accessed 22 March 2012).

Evans-Pritchard, E. E. (1951), Social Anthropology, London: Cohen \& West.

Fernandez, R., and E. Loban, (eds) (2009), Zamiyakal: Torres Strait Dance Machines, Thursday Island: Gab Titui Cultural Centre.

Fitzpatrick, K., ed. (2001), Thancoupie, Brisbane: Brisbane City Gallery.

Fourmile, H. (1989), 'The Aboriginal Art Market and the Repatriation of Aboriginal Cultural Property', Social Alternatives 8(1): 19-22.

Fourmile, H. (1996a), 'Aboriginal Identity and Tourism: A Changing Relationship', Tempus 5: 109-13.

Fourmile, H. (1996b), 'The Law of the Land: Whose Law, Whose Land?', Tempus 5: 45-50.

Fox Galleries (2003), Songlines: Emerging Queensland Indigenous Artists, Brisbane: Keeaira Press.

Frederick, U. (1992), Cape York to Cairns: Reinventing Meaning in Contemporary Aboriginal Art, Honours diss., University of Western Australia.

Gab Titui Cultural Centre (2008), Gab Titui Indigenous Art Award 2008, Thursday Island: Gab Titui Cultural Centre.

Gab Titui Cultural Centre (2009a), Gab Titui Indigenous Art Award 2009, Thursday Island: Gab Titui Cultural Centre.

Gab Titui Cultural Centre (2009b), 'Ngalmun Lagau Minaral'. Available online: http:// www.gabtitui.com.au/index.php?option=com_content\&view=article\&id=36\&Ite mid=33 (accessed 5 November 2012).

Gab Titui Cultural Centre (2010), Gab Titui Indigenous Art Award 2010, Thursday Island: Gab Titui Cultural Centre.

Geertz, C. (1973), 'Thick Descriptions: Toward an Interpretative Theory of Culture', in Interpretation of Cultures, 3-32, New York: Basic Books.

Gell, A. (1998), Art and Agency: An Anthropological Theory, Oxford: Clarendon Press.

George, T., G. Musgrave and Ang-Gnarra Rangers (1995), Our Country Our Art Our Quinkans, Laura: Ang-Gnarra Aboriginal Coorporation.

Gibson, L. (2013), We Don't Do Dots: Aboriginal Art and Culture in Wilcannia, New South Wales, Canon Pyon, England: Sean Kingston.

Goddard R. H., and S. R. Mitchell (1941), 'Aboriginal Rock Sculpture and Stencilling in the Carnarvon Ranges', Oceania 11(4): 368-373.

Goodman, N. (2007-12), 'Abstraction'. Available online: http://www.oxfordartonline. com/subscriber/article/grove/art/T000257?q=abstraction\&search=quick\&pos=1\&_ start $=1 \#$ firsthit (accessed 27 June 2012).

Gray, M., B. Hunter and M. Howlett (2013), 'Indigenous Employment: A Story of Continuing Growth', Centre for Aboriginal Economic Policy Research, Topical Issues 2, Canberra: CAEPR.

Haddon, A. C. (1890 a), 'Legends from Torres Straits I', Folklore 1: 47-81.

Haddon, A. C. (1890b), 'Legends from Torres Straits II', Folklore 1: 172-96. 
Haddon, A. C. (1935), Reports of the Cambridge Anthropological Expedition to Torres Straits, London: Cambridge University Press.

Halseth, O. (1925), 'The Acculturation of the Pueblo Indians', El Palacio 18: 254-68. Halseth, O. (1926), 'The Revival of Pueblo Pottery Making', El Palacio 21: 135-54.

Harrison, N. (2011), Teaching and Learning in Aboriginal Education, 2nd edn, Sydney: Oxford University Press.

Healy, C. (2008), Forgetting Aborigines, Sydney: University of New South Wales Press. Herle, A., and S. Rouse, eds (1998), Cambridge and the Torres Strait: centenary Essays on the 1898 Anthropological Expedition, Cambridge: Cambridge University Press.

Hewett, E. (1922), 'Primitive Art', El Palacio 13: 9.

Hollingsworth, D. (1992), 'Discourses on Aboriginality and the Politics of Identity in Urban Australia, Oceania 63: 137-55.

Hollingsworth, M. (1993), 'Printmaking at Cairns Tafe', in Getting into Prints: A Symposium on Aboriginal Printmaking, 48-53, Darwin: Association of Northern and Central Australian Aboriginal Artists.

Idriess, I. ([1947] 1890), Drums of Mer, Sydney: Angus and Robertson.

Itten, J. (1961). The Art of Colour: The Subjective Experience and Objective Rationale of Colour, New York: Van Nost and Reinhold.

Itten, J. (1963). Design and Form: The Basic Course at the Bauhaus, London: Thames and Hudson.

Janke, T. (1998), Our Culture: Our Future: Report on Australian Indigenous Cultural and Intellectual Property Rights, Sydney: Michael Frankel and Company, Solicitors.

Jenkins, R. (1996), Social Identity, London and New York: Routledge.

Jones, D. J., and J. Hill-Burnett (1982), 'The Political Context of Ethnogenesis: An

Australian Example', in M. Howard (ed.), Aboriginal Power in Australian Society,

214-46, St Lucia: University of Queensland Press.

Jones, P. (2008), 'The "Idea Behind the Artefact": Norman Tindale's Early Years as a Salvage Ethnographer', in N. Peterson, L. Allen and L. Hamby (eds), The Makers and Making of Indigenous Australian Museum Collections, 315-54, Melbourne: Melbourne University Press.

Kahn, K. (2008), 'The Man Who Collected Everything: W.E. Roth', in N. Peterson, L. Allen and L. Hamby (eds), The Makers and Making of Indigenous Australian Museum Collections, 163-89, Melbourne: Melbourne University Press.

Kandinsky, W. (1914), Concerning the Spiritual in Art, New York: Dover.

Kaus, D. (2004), 'Material Culture Collections and Research from Torres Strait', Memoirs of the Queensland Museum, Cultural Heritage Series 3(1): 93-104.

Kaus, D. (2008), 'Professionals and Amateurs: Different Histories of Collecting in the National Ethnographic Collection', in N. Peterson, L. Allen and L. Hamby (eds), The Makers and Making of Indigenous Australian Museum Collections, 281-312, Melbourne: Melbourne University Press.

Keeffe, K. (1988), 'Aboriginality: Resistance and Persistence', Australian Aboriginal Studies 1: 67-81. 
Keen, I., ed. (1988), Being Black: Aboriginal Cultures in 'Settled' Australia, Canberra: Aboriginal Studies Press.

Kehren, K. (2016), 'Cairns artist Robert “Tommy” Pau wins national prize', Cairns Post, 2 August. Available online: https://www.cairnspost.com.au/entertainment/ cairns-artist-wins-national-prize/news-story/6bb892360f2f7cce9c6cd83ea6fb9651 (accessed 31 October 2018).

Kidd, R. (1997), The Way We Civilise: Aboriginal Affairs - the Untold Story, St Lucia: University of Queensland Press.

Kleinert, S., and M. Neal (2000), The Oxford Companion to Aboriginal Art and Culture, Oxford: Oxford University Press.

Kuper, A. (1973), Anthropologists and Anthropology: The British School 1922-1972, London: Clarke, Doble \& Brendon.

Laver, J. (2010), 'Précis', in P. Brinkman (ed.), Malu Minar [Sea Pattern]: Art of the Torres Strait, 13-16, Cairns: Cairns Regional Gallery.

Lawrie, M. (1970), Myths and Legends of Torres Strait, St. Lucia: University of Queensland Press.

Layton, R. (1991), The Anthropology of Art, Cambridge: Cambridge University Press.

Layton, R. (2003), 'Art and Agency: a Reassessment', Journal of Royal Anthropological Institute 9: 447-64.

Louth, S. (2017), 'Indigenous Australians: Shame and Respect', in E. Vanderheiden and C. H. Mayer (eds), The Value of Shame: Exploring a Health Resource in Cultural Contexts, 187-200, Mainz: Springer International.

Loveday, P. and P. Cooke, eds (1983), Aboriginal Arts and Crafts and the Market, Darwin: Australian National University North Australian Research Unit.

Marcus, G. E. and M. F. Fischer (1986), Anthropology as Cultural Critique: An Experimental Moment in the Human Sciences, Chicago, IL: University of Chicago Press.

Martin, D. (1995), Money, Business and Culture: Issues for Aboriginal Economic Policy, Canberra: CAEPR Discussion Paper No. 101.

Martin, T. (2014), “ "Socialist Paradise” or "Inhospitable Island”? Visitor Response to Palm Island in the 1920s and 1930s', Aboriginal History 38: 131-53.

McConnel, U. (1935), 'Inspiration and Design in Aboriginal Art', Art in Australia, May: 49-68.

McConnel, U. (1939), 'Social Organisation of the Tribes of Cape York Peninsula, North Queensland', Oceania 10(1): 54-72.

McLean, B. (2011), 'The Power of Young Men: The Contemporary Torres Strait Print Movement', in The Torres Strait Islands, South Brisbane: Queensland Art Gallery and Gallery of Modern Art; State Library of Queensland; Queensland Museum; Queensland Performing Art Centre.

McLean, I. (1998), White Aborigines: Identity Politics in Australian Art, New York: Cambridge University Press. 
Meek, V., and R. Harrold, eds (1989), Tafe and the Reconstruction of Higher Education: A Conference Summary, Armidale: Dept of Continuing Education, University of New England.

Merlan, F. (2001), 'Aboriginal Cultural Production into Art: The Complexity of Redress', in C. Pinney and N. Thomas (eds), Beyond Aesthetics: Art and the Technologies of Enchantment, 201-34, Oxford: Berg.

Michaels, E. (1994), Bad Aboriginal Art: Traditional, Media and Technological Horizons, St Leonards, NSW: Allen \& Unwin.

Mitchell, W. J. T. (1986), Iconology: Image, Text, Ideology. Chicago, IL: University of Chicago Press.

Moore, D. R. (1979), Islanders and Aborigines of Cape York: An Ethnographic Reconstruction Based on the 1848-1850 'Rattlesnake' Journals of O. W. Brierly and Information He Obtained from Barbara Thompson, Canberra: Australian Institute of Aboriginal Studies.

Moore, D. R. (1984), The Torres Strait Collections of A. C. Haddon, London: British Museum Press.

Moore, D. R. (1989), Arts and Crafts of Torres Strait, Aylesbury, UK: Shire.

Morecombe, M. (2000), Field Guide to Australian Birds, Archerfield: Steve Parish.

Morphy, H. (1991), Ancestral Connections: Art and an Aboriginal System of Knowledge, Chicago, IL: University of Chicago Press.

Morphy, H. (1992), 'From Dull to Brilliant: The Aesthetics of Spiritual Power among the Yolngu', in J. Coote and A. Shelton (eds), Anthropology, Art and Aesthetics, 181-208, Oxford: Clarendon Press.

Morphy, H. (1998), Aboriginal Art, London: Phaidon Press.

Morphy, H. (2008), Becoming Art: Exploring Cross-Cultural Categories, Sydney: University of New South Wales Press.

Morphy, H. (2009), 'Art as a Mode of Action: Some Problems with Gell's Art and Agency', Journal of Material Culture 14(1): 5-27.

Morphy, H., and M. Perkins, eds (2006), The Anthropology of Art: A Reader, Carlton: Blackwell.

Mounter, B. (2017), 'Indigenous Shield Art in Cairns CBD a Symbol of War and Peace', ABC News, 5 January. Available online: https://www.abc.net.au/news/2017-0501/shield-art-in-cairns-cbd-a-symbol-of-war-and-peace/8486170 (accessed 29 October 2018).

Mundine, D., and M. Aird, eds (2007), Sunshine State Smart State: Vernon Ah Kee, Richard Bell, Fiona Foley, Lindy Lee, Tracey Moffatt, Ken Thaiday, Thanakupi, Judy Watson, William Yang, Campbelltown: Campbelltown Art Centre.

Munn, N. (1960), Walbiri Iconography: Graphic Representation and Cultural Symbolism in a Central Australian Society, Ithaca, NY: Cornell University Press.

Myers, F. (1991a), Pintupi Country, Pintupi Self: Sentiment, Place, and Politics among Western Desert Aborigines, Berkley: University of California Press. 
Myers, F. (2002), Painting Culture: The Making of an Aboriginal High Art, Durham: Duke University Press.

Myers, F. (2004), 'Ontologies of the Image and Economies of Exchange', American Ethnologist 31: 5-20.

Newstead, A. (2001), 'The Genesis and Development of Torres Strait Print Making in the Western Islands', in C. Alfonso and M. Kershaw (eds), Gelam Nguzu Kazi Dugong My Son, 5-12, Brisbane: Kubin Community Council.

O'connell, R., ed. (2007), Ailan Currents: Contemporary Printmaking from the Torres Strait, Cairns: KickArts Contemporary Arts.

O'connell, R. (2008), Billy Missi: Urapun Kai Buai - Contemporary Lino Prints from the Torres Strait, Cairns: KickArts Contemporary Arts.

Panofsky, E. (1970), 'Iconography and Iconology: An Introduction to the Study of Renaissance Art', in Meaning in the Visual Arts, 51-81, New York: The Overlook Press.

Perusco, A. (2008), 'Only Sticks and Bark: Ursula McConnel - Her Collecting and Collection', in, N. Peterson, L. Allen and L. Hamby (eds), The Makers and Making of Indigenous Australian Museum Collections, 419-45, Melbourne: Melbourne University Press.

Peterson, N. (2010), 'Other People's Lives: Secular Assimilation, Culture and Governability', in J. Altman and M. Hinkson (eds), Culture Crisis: Anthropology and Politics in Aboriginal Australia, 248-58, Sydney: University of New South Wales Press.

Philp, J. (2001), Past time: Torres Strait Islander Material from the Haddon Collection, 1888-1905: A National Museum of Australia Exhibition from the University of Cambridge, Canberra: National Museum of Australia Press.

Potter, K. K. (1999), 'James Houston, Armchair Tourism, and the Marketing of Inuit Art', in W Jackson Rushing, III (ed.), Native American Art in the Twentieth Century: Makers, Meanings, Histories, 39-56, New York: Routledge.

Quaill, A. (2003). 'Keeping and Sharing: The Tropical North Queensland Institute of TAFE', in Story Place: Indigenous Art of Cape York and the Rainforest, 200-3, South Brisbane, QL: Queensland Art Gallery.

Queensland Art Gallery (2009), Nurreegoo: the Art and Life of Ron Hurley, 1946-2002, South Brisbane, QL: Queensland Art Gallery.

Queensland Art Gallery (2010), Joe Rootsey: Queensland Aboriginal Painter, 1918-1963, South Brisbane, QL: Queensland Art Gallery.

Queensland Art Gallery (2011), The Torres Strait Islands, South Brisbane, QL: Queensland Art Gallery and Gallery of Modern Art; State Library of Queensland; Queensland Museum; Queensland Performing Art Centre.

Queensland Government (2018), 'Thursday Island (Waiben)'. Available online: https:// www.qld.gov.au/atsi/cultural-awareness-heritage-arts/community-histories/ community-histories-s-t/community-histories-thursday-island (accessed 30 October 2018). 
Robert Steele Gallery (2009), Torres Strait Islander Artists Dennis Nona and Alick Tipoti: Gaigai Ika Woeybadh Yatharewmka Legends through Patterns from the Past, New York: Robert Steele Gallery.

Robinson, B. (2006), 'Banggu Minjaany Arts and Cultural Centre', in Unreal

Shields: Revisiting Kingplates - Creating Etchings with Attitude, Cairns: Tropical North Queensland TAFE.

Robinson, B. (2007), 'From Mask to Paper', in R. Milledge (ed.), Ailan

Currents: Contemporary Printmaking from the Torres Strait, 8-11, Cairns: KickArts Contemporary Arts.

Roth, W. E., ed. ([1897] 1984), The Queensland Aborigines, Victoria Park:

Hesperian Press.

Roth, W. E. (1909), 'Fighting Weapons', North Queensland Ethnography Bulletin no. 13.

Records of the Australian Museum vol. 7.

Roth, W. E. (1910). 'Transport and Trade', North Queensland Ethnography Bulletin no.

13. Records of the Australian Museum vol. 7.

Rushing III, W. J., ed. (1999), Native American Art in the Twentieth Century: Makers, Meanings, Histories, New York: Routledge.

Sanders, W. (1993), 'Times of Persistent Unemployment'. Centre for Aboriginal Economic Policy Research, Discussion Paper 54, Canberra, CAEPR, Canberra: CAEPR.

Schmidt, C. (2012), “ “I Paint for Everyone” - the Making of Utopia Art', PhD diss.,

Research School of Humanities, The Australian National University.

Senate Standing Committee on Environment, Communications, Information

Technology and the Arts (2007), Indigenous Art - Securing the Future: Australia's

Indigenous Visual Arts and Craft Sector, Canberra: Commonwealth of Australia.

Sharp, N. (1992), Footprints along the Cape York Sandbeaches, Canberra: Aboriginal

Studies Press.

Sheehan, C. G. (2010), Meriba Gidhal: Torres Strait Island Treasures of the Margaret

Lawrie Collection, Brisbane: State Library of Queensland.

Spencer, H. (1896), The Principles of Sociology, London: Williams and Norgate.

Stevenson, K. (1989), " "Nothing New under the Sun” a History of Technical Education

in NSW and its Relationship with Higher Education, Particularly Cross-Sectoral

Articulation', in V. L. Meek and R. Harrold (eds), TAFE and the Reconstruction of

Higher Education: A Conference Summary, Armidale: Dept of Continuing Education, University of New England.

Stolte, G. (2012), 'Policy Mismatch and Indigenous Art Centres: The Tension between Economic Independence and Community Development', in N. Fijn, I. Keen, C. Lloyd and M. Pickering (eds), Indigenous Participation in Australian Economies II: Historical Engagements and Current Enterprises, 229-42, Canberra: ANU E Press. Stolte, G., L. Flinders, C. Creed and R. T. Pau (2015), 'An Aboriginal and Torres Strait Islander Approach to Intellectual Property: Industry Insight into the Development of Indigenous Cultural Protocols', International Journal of Cultural and Creative Studies 2(3): 64-75. 
Sutton, P. (1989), Dreamings: The Art of Aboriginal Australia, London: Viking.

Sutton, P. (2009), The Politics of Suffering: Indigenous Australia and the End of the Liberal Consensus, Melbourne: Melbourne University Press.

Taylor, L. (1996), Seeing the Inside: Bark Painting in Western Arnhem Land, New York: Clarendon Press.

Training and Further Education (TAFE) New South Wales (2010), 'Our History'. Available online: https://www.tafensw.edu.au/about/our_history.htm (accessed 1 May 2012).

Thomson, D. (1972), Kinship and Behaviour in North Queensland, Canberra: Australian Institute of Aboriginal Studies Press.

Thomson, J. (1989), Reaching Back: Queensland Aboriginal People Recall the Early Days at Yarrabah Mission, Canberra: Aboriginal Studies Press.

Trezise, P. J. (1971), Rock Art of South-East Cape York, Canberra: Australian Institute of Aboriginal Studies.

Tropical North Queensland Institute of TAFE (2006), Unreal Shields: Revisiting Kingplates: Creating Etchings with Attitude/Bannggu Minjany Arts \& Cultural Centre; Tropical North Queensland Tafe Art Students, Cairns: Tropical North Queensland TAFE.

Tropical North Queensland Institute of TAFE (2012), 'TAFE History'. Available online: http://www.tafe.qld.gov.au/about-tafe/tafe-qld/history/index.html (accessed 1 May 2012).

Turner, G. (1994), Making It National: Nationalism and Australian Popular Culture, St Leonards: Allen \& Unwin.

UMI Arts (2009), 'Strengthening Culture Story'. Available online: http://www.umiarts. com.au/index.php?option $=$ com_content $\&$ view $=$ article $\&$ id $=47 \&$ Itemid $=136$ (accessed 4 December 2012).

UMI Arts (2012), 'UMI Arts Big Talk One Fire Indigenous Cultural Festival 2012'. Available online: http://www.umiarts.com.au/index.php?option=com_content\&view $=$ article\&id=98\&Itemid $=149$ (accessed 4 December 2012).

Warren, R. J., ed. (2004), Wildflower: the Barbara Crawford Thompson Story, Brisbane: Raymond J Warren.

Wilcox, M. (1987), Blue and Yellow Don't Make Green, Cincinnati: North Light Books. Willis, W. S. Jr (1999), 'Skeletons in the Anthropological Closet', in D. Hymes (ed.), Reinventing, Anthropology, 121-51, Ann Arbor: University of Michigan Press.

Wilson, L. (1988). Thathilgaw Emeret Lu: A Handbook of Traditional Torres Strait Islands Material Culture, Brisbane: Department of Education, Queensland.

Wilson, L. (1993), Kerkar Lu: Contemporary Artefacts of the Torres Strait Islanders, Brisbane: Department of Education.

Wirrimbirra Flora and Fauna Sanctuary (2010). 'Pied Imperial-Pigeon'. David G. Stead Memorial Wild Life Research Foundation of Australia. Available online: http://www. wirrimbirra.com.au/Pied\%20imperial\%20pigeon.htm (accessed 25 January 2013).

Wright, F. and F. Morphy (2000), The Art \& Craft Centre Story, Canberra: ATSIC. 